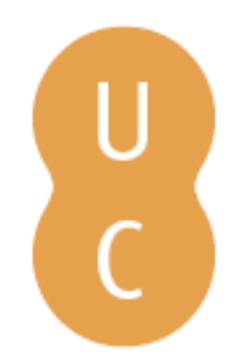

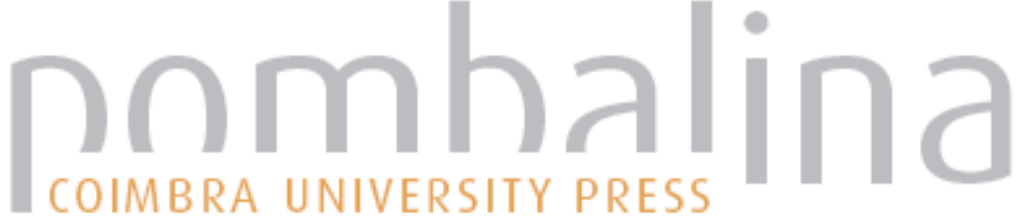

\section{Uma perspetiva histórica da Mafalala}

Autor(es): Laranjeira, Rui

Publicado por: Imprensa da Universidade de Coimbra

URL

persistente:

URI:http://hdl.handle.net/10316.2/39294

DOI:

DOI:http://dx.doi.org/10.14195/978-989-26-1220-1_4

Accessed : $\quad$ 26-Apr-2023 13:32:40

A navegação consulta e descarregamento dos títulos inseridos nas Bibliotecas Digitais UC Digitalis, UC Pombalina e UC Impactum, pressupõem a aceitação plena e sem reservas dos Termos e Condições de Uso destas Bibliotecas Digitais, disponíveis em https://digitalis.uc.pt/pt-pt/termos.

Conforme exposto nos referidos Termos e Condições de Uso, o descarregamento de títulos de acesso restrito requer uma licença válida de autorização devendo o utilizador aceder ao(s) documento(s) a partir de um endereço de IP da instituição detentora da supramencionada licença.

Ao utilizador é apenas permitido o descarregamento para uso pessoal, pelo que o emprego do(s) título(s) descarregado(s) para outro fim, designadamente comercial, carece de autorização do respetivo autor ou editor da obra.

Na medida em que todas as obras da UC Digitalis se encontram protegidas pelo Código do Direito de Autor e Direitos Conexos e demais legislação aplicável, toda a cópia, parcial ou total, deste documento, nos casos em que é legalmente admitida, deverá conter ou fazer-se acompanhar por este aviso.

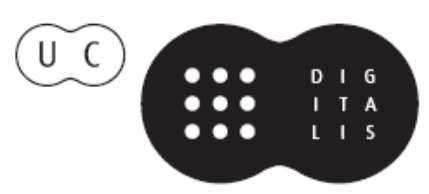


MARGARIDA CALAFATE RIBEIRO

WALTER ROSSA

[ORG.]

\section{MEMÓRIAS \\ E ESPAÇOS \\ DE UM LUGAR}

II

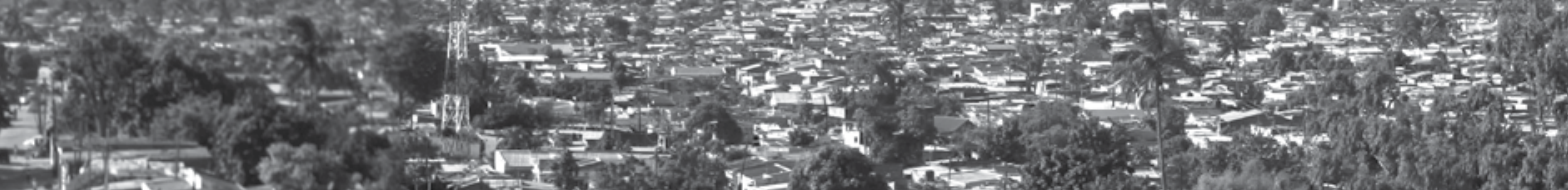

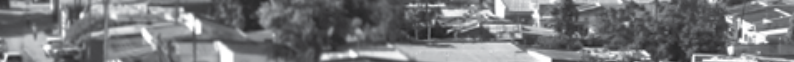

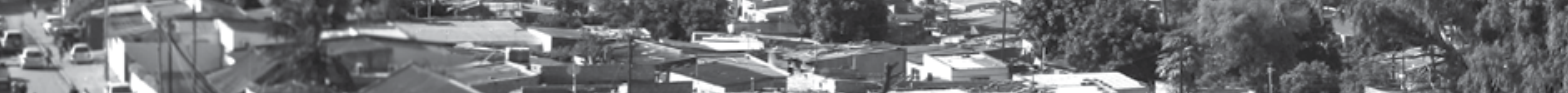

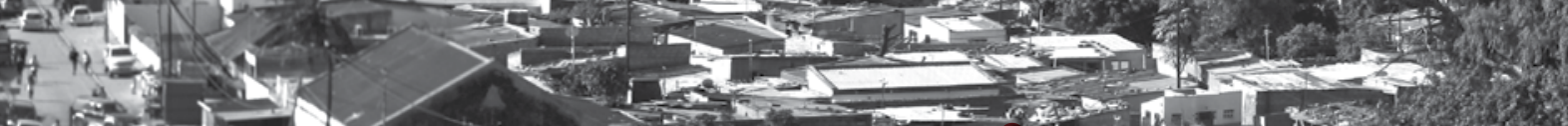

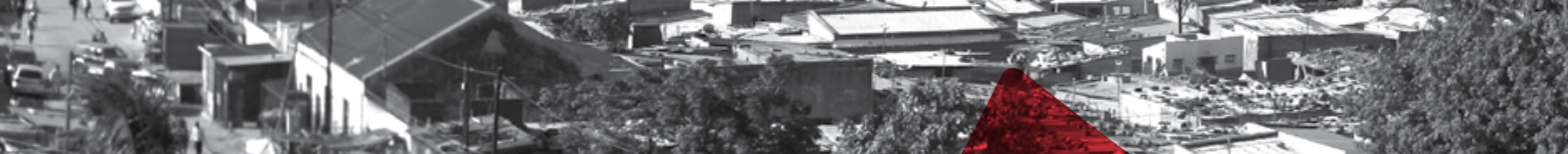
a.

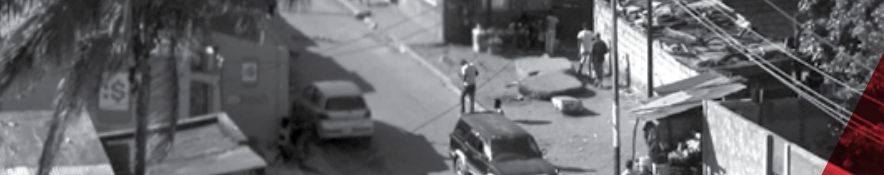

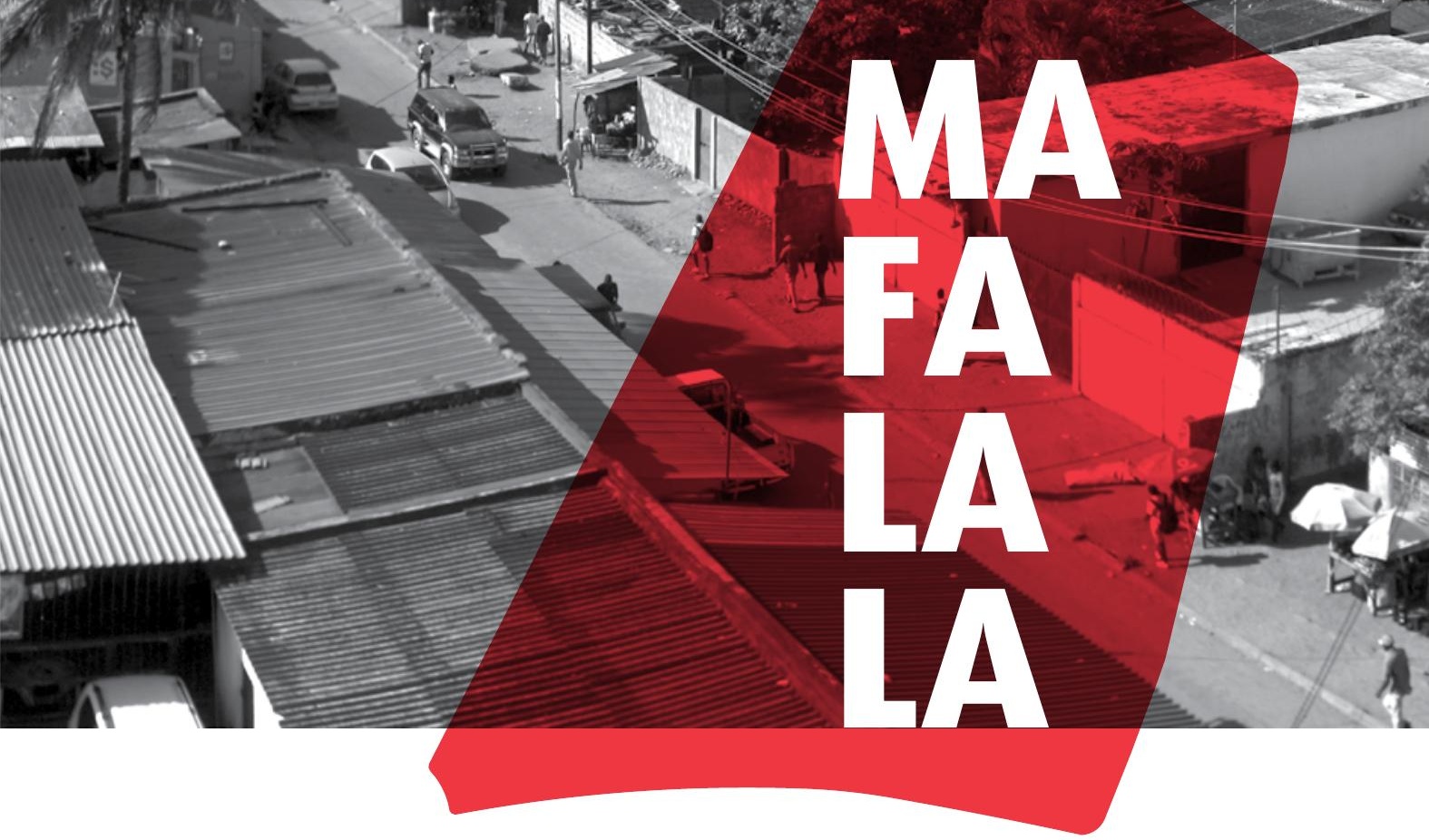




\section{UMA PERSPETIVA HISTÓRICA DA MAFALALA}

Rui Laranjeira

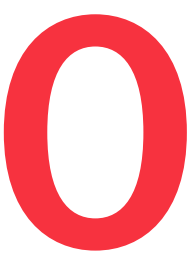

presente texto oferece uma abordagem histórica ao bairro da Mafalala desde a sua formação até ao presente. Faz parte de uma pesquisa mais vasta sobre este bairro, que será publicada em livro, onde alguns assuntos aqui abordados serão discutidos com maior profundidade. A Mafalala é um dos bairros mais emblemáticos de Moçambique, ao qual ainda não se fez jus. Lembremos que importantes figuras do panorama político, social, cultural e desportivo de Moçambique viveram ou nasceram aqui.

Neste texto, além do recurso a bibliografia e fontes primárias, decidimos trabalhar também com vozes anónimas, através de entrevistas a habitantes do bairro que nos facultassem histórias vivas e coloridas da Mafalala, fugindo deste modo ao padrão habitual em que os famosos falam em nome da maioria. Julgamos que um trabalho desta natureza é importante para a criação de referências e de uma memória própria dos habitantes do bairro.

\section{Antecedentes históricos}

Antes de nos debruçarmos propriamente sobre a Mafalala, torna-se necessário fazer uma breve descrição histórica da evolução da então cidade de Lourenço Marques, da sua passagem de povoação a capital da colónia de Moçambique e das várias ocupações que sofreu por parte 


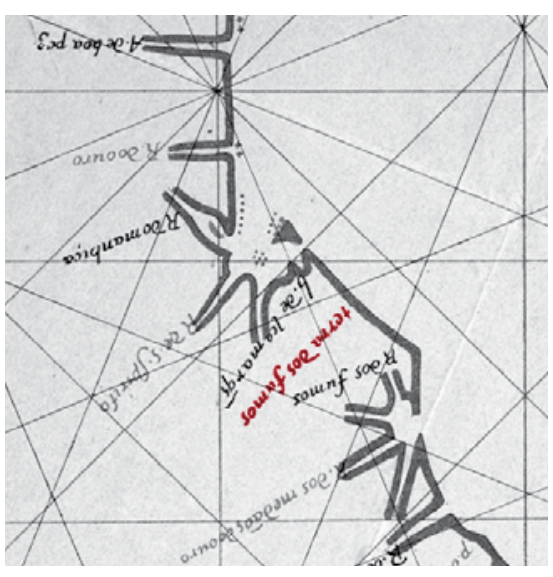

Detalhe da localização da Baía de Lourenço Marques da Carte de la côte d'Afrique de M. de Mesquita Perestrello, 1576. de outros países europeus. Deste modo, recordemos que a zona onde se desenvolveu grande parte da cidade de Lourenço Marques, atual Maputo, pertencia à dinastia Mpfumo, unidade política que existia desde o século $\mathrm{XVI}$, juntamente com as de Tembe, Inhaca, Libombo e Manhiça. Esta informação provém do relato de um náufrago da nau São Bento, Manoel de Mesquita Perestrello, ocorrido naquele século na baía de Maputo, de acordo com o estudo realizado por Lemos (1987: 6).

\section{A Descoberta da Baía de Lourenço Marques}

A baía de Lourenço Marques foi alcançada pelo navegador e comerciante português Lourenço Marques, por volta de 1544/45. O navegador, o primeiro europeu a fazer o reconhecimento de toda a região que se chamava a Baía do Espírito Santo, fora enviado pelo governo da llha de Moçambique à procura de marfim, que era bastante procurado na Índia. Como resultado, as viagens de mercadores e comerciantes portugueses à região passaram a ter uma regularidade anual ou bienal a partir da Índia e, mais tarde, a partir da Ilha de Moçambique, com vista ao comércio do marfim, que era trocado por tecidos e missangas. Em homenagem ao navegador, o rei português D. João III batizou a baía com o seu nome (Liesegang, 1987: 6).

Segundo Lemos (1987: 6), antes não tinha havido qualquer tentativa de fixação permanente na baía, pois esta ficava fora da rota de navegação entre a llha de Moçambique e o Cabo da Boa Esperança. Os navegadores aportavam à baía para abrigo ou para realizar pequenas trocas comerciais com as populações costeiras. Foi então que surgiram os topónimos portugueses para a região, nomeadamente Baía da Boa Paz, Baía Formosa, Baía da Boa Morte e Baía (rio) Da Lagoa ou 
Da Alagoa, sendo a última designação a que mais se popularizou devido à presença inglesa e de outros povos europeus que passaram a frequentá-la.

Outros navegadores e comerciantes europeus, de origem austríaca, francesa, holandesa e inglesa, passaram também a frequentar a baía.

Em 1721, numa altura em que a presença dos portugueses passara a ser irregular, os holandeses instalaram-se e construíram o Forte Lagoa, na Praia da Maxaquene, no atual campo do Desportivo, nas terras de Mpfumo. Cinco anos depois, o forte era conhecido como Lydzaamheid, que significava tolerância ou liberdade. Porém, a presença holandesa terminaria em 1730 devido à insalubridade e ao insucesso comercial (Lemos, 1987: 7).

Em 1777, chegavam os austríacos, que, através de negociações efetuadas com os reinos de

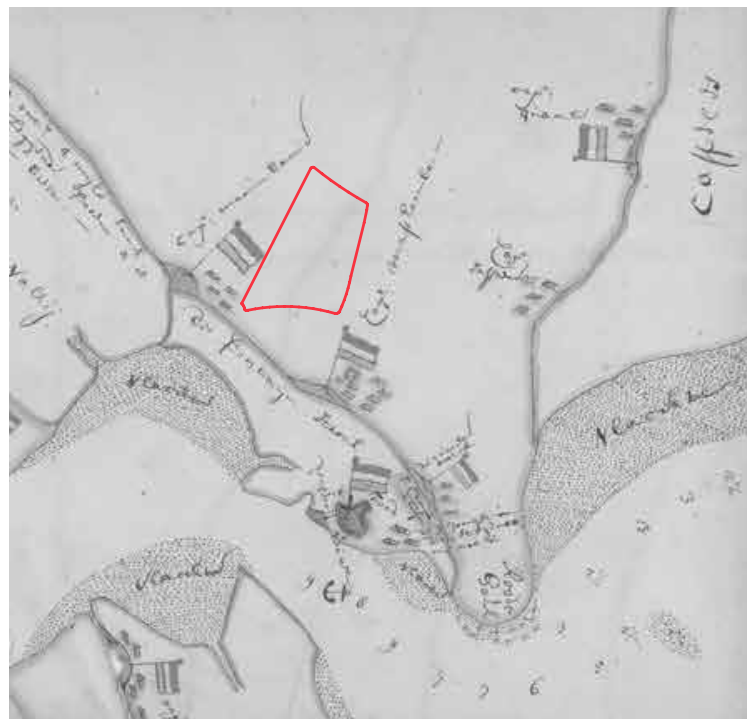

Detalhe do Mapa (holandês) com as feitorias na Baía de Lourenço Marques, 1726. Sobreposta a delimitação atual do Bairro da Mafalala. Tembe, Matola e Mpfumo, conseguem estabelecer-se nas zonas ribeirinhas destes reinos e criar feitorias. A sua presença terminou em 1781 com uma expedição militar portuguesa enviada de Goa no mesmo ano, com o propósito de repor a hegemonia portuguesa na baía (Lemos, 1987: 7). Após esta ação, o Governador-Geral interino de Moçambique, Vicente Caetano da Maia e Vasconcelos, decide-se pela instalação de uma feitoria, casa forte e presídio, para proteger o comércio português na região. Com esse propósito é nomeado, a 25 de novembro de 1781, o Capitão-Mor e Governador Joaquim de Araújo.

Entretanto os ingleses, que se tinham fixado em Natal em 1843, começaram a demonstrar interesse pela baía, chegando a pôr em causa a legitimidade portuguesa na região. Esta pretensão seria frustrada pela sentença arbitral, proferida a 24 de julho de 1875, pelo Marechal 
francês Mac Mahon, então presidente da República Francesa, a favor dos portugueses, repondo a soberania de Portugal sobre a região (Lemos, 1987: 7).

Como resultado do interesse britânico pela baía, esta ficou conhecida internacionalmente como Delagoa Bay, a ponto de a mercadoria endereçada para Lourenço Marques ser feita com esta designação, o que levou até o Governador-Geral José Cabral (1926-1937) a tomar a drástica decisão de devolver à proveniência toda a mercadoria e correspondência enviada com o endereço Delagoa Bay (Lemos, 1987: 7).

\section{Lourenço Marques: de povoado a cidade e capital da colónia de Moçambique}

Ao longo do processo de ocupação da baía, o povoado, que inicialmente se limitava à praia da Maxaquene, evoluiu para povoação. Importa referir que Lourenço Marques ganhou importância a partir do século XIX como resultado do movimento migratório dos boers do Cabo - o Great Trek - para o Transvaal, que emigravam para evitar o domínio britânico. Para estes, a sua independência e o seu desenvolvimento económico só seriam possíveis com uma saída para o mar, e o porto de Lourenço Marques oferecia-se como a melhor opção. Com este propósito, iniciou-se em 1871 a construção da estrada de Lydemburgo e, em 1886, a construção da linha férrea Lourenço Marques-Pretória, concluída em 1894 (Lima, 1971: 193-194). Outro aspeto a considerar foi a descoberta, em 1887, das jazidas de ouro de Johannesburg, o que incrementou, de forma considerável, o desenvolvimento de Lourenço Marques e contribuiu decisivamente para a construção da ferrovia (Liesegang, 1987: 20).

Como resultado deste empreendimento, o movimento de pessoas e mercadorias de Lourenço Marques para Pretória aumentou consideravelmente, contribuindo para o crescimento da povoação (Lemos, 1987: 11). Nesta sequência, antevendo a importância de Lourenço Marques como um entreposto comercial de referência, a povoação é elevada à categoria de vila a 9 de dezembro de 1876, e à de cidade por decreto real de 10 de novembro de 1887, com o seguinte teor: 
Tomando em consideração o notável incremento que tem tido a'villa de Lourenço Marques, capital d'districto do mesmo nome na provincia de Moçambique, em resultado dos melhoramentos materiaes ali ultimamente realisados, e attendendo, a excepcional importancia que toda aquella villa como o seu porto hão de adquirir com a próxima exploraçao do caminho de ferro que há de ligar, por uma communicacao facil e rapida, aquele districto com a republica do Transvaal, importancia que é ja hoje muito sensivel no augmento da navegação e do commercio, e na transformação rapida que se esta operando nas condições economicas e sociaes d'aquella povoação: hei de por bem decretar que a mencionada villa seja elevada a categoria de cidade, com a denominação de: cidade de Lourenço Marques. / O ministro e secretário d'estado dos negócios da marinha e ultramar assim o tenha entendido e faça executar. / Paço, em 10 de Novembro de 1887 =REI= Henrique de Macedo. (apud Lemos, 1987: 12)

A pouca população branca residente no perímetro da cidade sentia-se ameaçada pelos reinos africanos que efetuavam incursões armadas: os reinos de Mpfumo e Magaia. A área a que pertencia o extinto concelho de Lourenço Marques continuaria a ser chamada Mpfumo, que era o nome da principal chefatura da margem norte da baía e da dinastia que nela reinava aquando da chegada dos portugueses no início do século XVI. Essa chefatura tinha sido reduzida territorialmente à Zixaxa, e praticamente desapareceu em 1895 com a prisão e deportação para os Açores (juntamente com Ngungunhane) do seu último chefe, Nuamantibjane (Lemos, 1987: 10). Nuamantibjane tinha perdido as terras de Polana, Mahé e outras como Maxaquene, que tinham sido retiradas do seu domínio pelos portugueses. Este chefe nativo tivera como aliado Mahazul, chefe Magaia, tendo como rivais os chefes Matola e Moamba, que foram derrotados a 2 de fevereiro de 1895, na batalha de Marracuene. Com a derrota definitiva de Nuamantibjane pelos portugueses em 21 de outubro de 1895, em Magul, termina a revolta de Lourenço Marques, abrindo-se caminho para a queda do império de Gaza, cuja capital se situava em Manjacaze (Lemos, 1987: 11). 
Os limites da cidade no último quartel do século XIX estendiam-se até ao quartel da polícia, atual quartel-general do exército, localizado na Avenida 24 de Julho. O quartel tinha sido construído entre 1887 e 1893 com o propósito de constituir a guarda avançada colonial da cidade e proteger a Estrada de Lydemburgo dos ataques das chefaturas africanas (Lima, 1966: 34-35).

Como resultado da ocupação militar de 1895, transferiu-se o centro político-administrativo da colónia da llha de Moçambique para Lourenço Marques. Esta medida foi tomada a 22 de novembro de 1898, pelo Governador-Geral, Baltazar Freire Cabral, que "determinava que a partir de 1 de Dezembro daquele ano, até novo aviso, a sede de governo e a sua secretaria-geral passava a ser em Lourenço Marques" (Lemos, 1987: 12). Em termos jurídicos, a transferência só viria a ser consumada quando foi decretada a reforma administrativa da colónia, a denominada Reorganização Administrativa da Província de Moçambique, datada de 23 de maio de 1907, que estabelece no seu artigo $1 .^{\circ}$ o seguinte: "A Província de Moçambique compreende todo o território Portuguez na África Oriental. A sua capital é a cidade de Lourenço Marques" (Lemos, 1987: 12).

\section{0 surgimento da Mafalala}

A Mafalala formou-se como resultado da ocupação portuguesa da região sul de Moçambique. Desenvolveu-se num território que era pertença da dinastia Mpfumo, da etnia ronga (Pereira, 1972: 4). A ocupação do espaço que deu origem à Mafalala obedeceu a dois momentos: um primeiro, em 1875, quando há um incêndio na povoação que quase a destruiu em virtude do material de construção das palhotas ser inflamável; e um segundo, quando se efetiva a derrota do estado de Gaza, em 1895, a que se seguiu a expropriação de terrenos e a expulsão da população autóctone dos seus territórios.

Em 1876, o então governador Augusto de Castilho emitiu um dispositivo legal que proibiu a construção de palhotas e casas com cobertura em capim dentro do perímetro da povoação. Considera-se que a tomada desta medida levou a que a população negra que habitava a povoação fosse obrigada a deslocar-se para as zonas altas, que compreendiam 
as encostas da Maxaquene e Mahé, habitadas maioritariamente pela população nativa, vista como hostil pelos europeus, em virtude dos ataques que esta conduzia sobre a zona por eles habitada (xilunguíne) (Lemos, 1988: 51-52).

A população negra que habitara a povoação antes do incêndio era de origem diversa, compreendendo gente da Ilha de Moçambique, população proveniente das ilhas do oceano Índico, nomeadamente Comores e Zanzibar, vulgarmente conhecidos como mujojos. Muitos tinham vindo de forma voluntária, à procura de melhores condições de vida, mas outros foram trazidos pelos seus patrões. Eram marinheiros, alfaiates, artesãos, mainatos, soldados, cozinheiros e escravos. Foi portanto este grupo que se viu obrigado a deslocar-se para a encosta logo após a implementação da medida do governador Castilho (Lemos, 1988: 49-50).

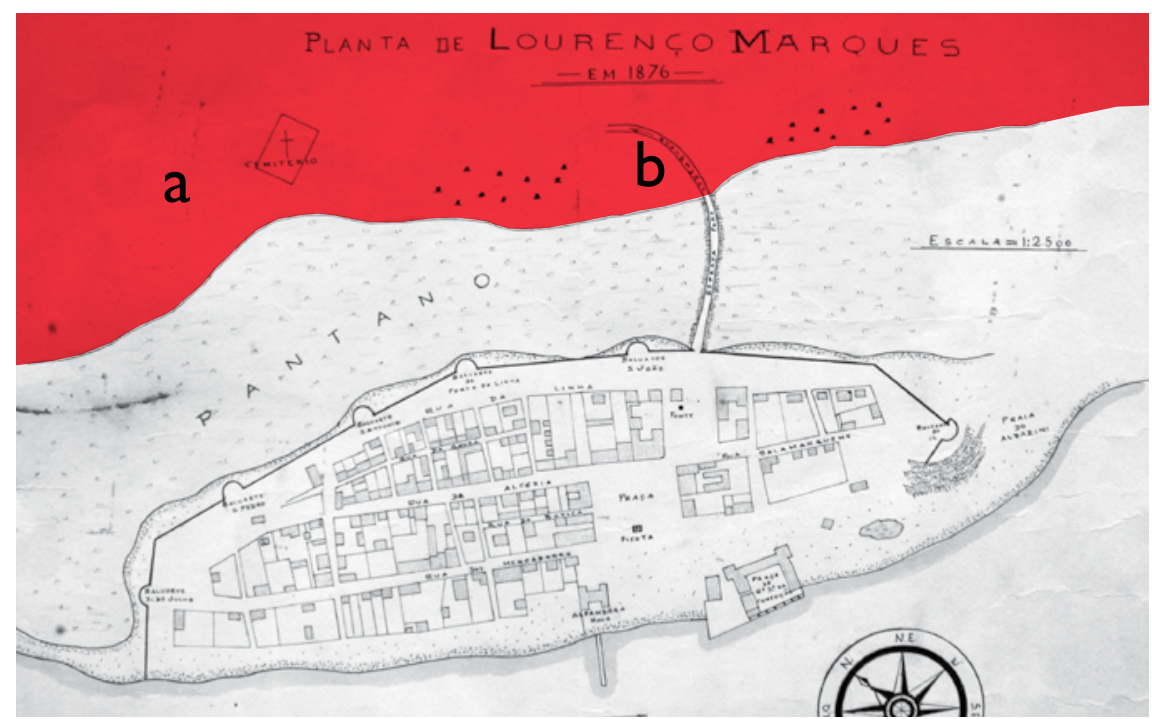

Planta de Lourenço Marques, em 1876. "a" e "b" indicam, respetivamente, as localizações de Mahé e Maxaquene.

William Joest, citado por Lemos (1988: 50), em relato da sua passagem por Lourenço Marques, por volta de 1884, afirma que os negros não eram tolerados à noite no interior da povoação e que habitavam as terras altas da Maxaquene e Mahé, chegando aos milhares. A ameaça constituída por estes grupos para a cidade colonial só viria a terminar 


local onde se dançava lifafala, talvez dissessem ya ka mafalala, o que significa vamos ao local onde se dança lifalala'.

Hoje a Mafalala é o bairro suburbano que se encontra mais próximo do centro da cidade e, por essa razão, tornou-se numa das áreas preferenciais para habitação por parte das pessoas de poucas posses. Segundo Mendes (1985: 339-341), esta zona apresentava o nível de densidade populacional mais alto da cidade com cerca de 150 a 250 hab./ha. E, nas imediações da Avenida Marien N'Gouabi (ex-Caldas Xavier), a densidade era mais alta ainda com aproximadamente 200 hab./ha., sendo a maior parte dos habitantes negros. Em relação ao tipo de construção, a autora identifica cinco tipos, nomeadamente: alvenaria, caniço e zinco, madeira e zinco, palhotas maticadas e palhotas. O maior número de habitações era de palhotas maticadas. As casas de alvenaria encontravam-se perto dos principais eixos industriais (Av. do Trabalho, Av. de Angola, R. do Xipamanine e Av. Craveiro Lopes), sendo ocupadas por habitantes com melhores posses e, portanto, melhores empregos (Mendes, 1985: 339-341).

Em 1950, no relatório da inspeção ordinária ao concelho de Lourenço Marques, era referido que os indígenas de Lourenço Marques eram principalmente marceneiros, pintores, barbeiros, lavadeiras, alfaiates, costureiros, sapateiros, engraxadores, negociantes nos mercados e vendedores ambulantes. Cerca de vinte anos depois, em relatório semelhante elaborado pelo inspetor Pereira (1972), não se verifica uma diferença significativa em relação às profissões da população negra, se considerarmos que grande parte das atividades exercidas era de natureza manual.

A população negra encontrava-se empregada nos Caminhos de Ferro, transportes e na câmara municipal. Outra parte trabalhava nas fábricas e oficinas, principalmente nas fábricas de descasque de castanha de cajú, que davam trabalho a centenas de mulheres (Pereira, 1972: 4). E importa ainda registar, segundo Pereira, que:

Para além dos negros habitavam este bairro brancos pobres. Este grupo era composto por operários, pequenos funcionários, empregados dos serviços municipalizados de viação, e em geral de pessoas de recursos mais fracos (Pereira, 1972: 11). 
Os macuas que habitavam o bairro provinham de Nampula, dos distritos de Angoche, Mossuril, Nacala e da Ilha de Moçambique. Eram na sua maioria marinheiros e carpinteiros. De acordo com Abissínia Aly, na entrevista referida, os primeiros a chegar à Mafalala terão sido chefes desterrados das suas zonas de origem por se recusarem a pagar o imposto ou terem oferecido resistência durante o processo de ocupação efetiva. Mas a grande maioria vinha em processo migratório, procurando melhores condições de vida. Tinham duas mesquitas, a Cadria e a Chadulia, que eram locais de convivência social e de passagem de valores culturais no seio da comunidade.

Apesar desta predominância macua no início, o bairro sempre foi multiétnico e multicultural, tal a diversidade de grupos étnicos e de culturas, ainda que cada grupo possuísse os seus espaços próprios de socialização. Segundo alguns dos nossos entrevistados, a ocupação dos espaços obedecia ao poder económico dos seus habitantes, pois as áreas próximas das principais avenidas eram mais caras. Por isso, nessa zona era usual encontrar brancos ou mestiços, estando a maioria dos negros no interior do bairro. Apesar destes grupos terem espaços de socialização distintos, o relacionamento entre os grupos era amigável, havendo evidências de casamentos entre estes sem discriminação.

Dançarinas de marrabenta, década de 1950

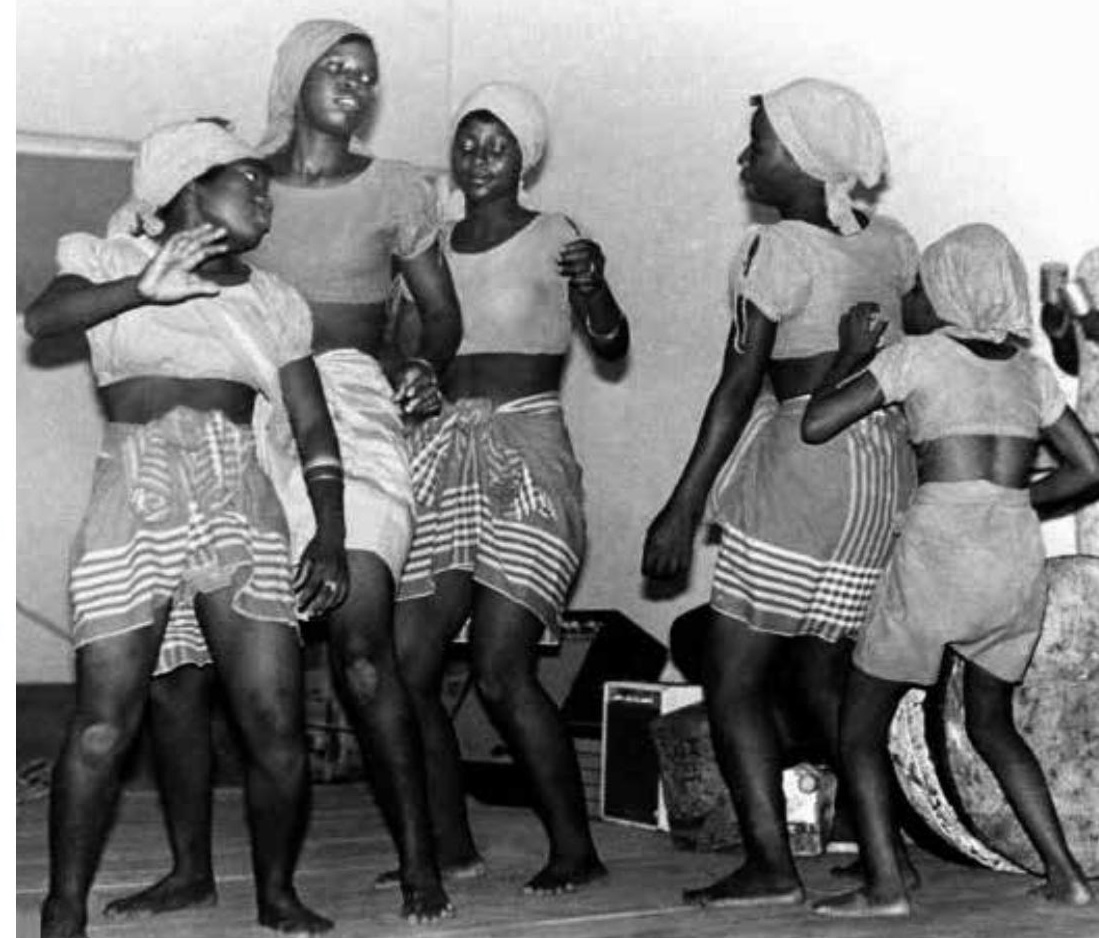


Entre os habitantes do bairro, podemos destacar os comoreanos, grupo de indivíduos provenientes das ilhas Comores que aqui se estabeleceram à procura de melhores condições de vida. Na sua maioria eram empregados na área da restauração, hotéis, cafés e como eram também falantes de francês eram os preferidos pelos proprietários deste tipo de estabelecimentos. Pelo facto de serem homens solteiros, muitos constituíram famílias com mulheres locais, havendo os que se mantiveram em Lourenço Marques até à sua morte², enquanto outros regressavam ao seu país de origem ${ }^{3}$. Um dos locais mais conhecidos da zona suburbana, pertença deste grupo, é Os Comoreanos - cabaré da Mafalala - local que Laranjeira (2014: 35), citando Craveirinha (1969: 15-16), aponta como um espaço onde a marrabenta ${ }^{4}$ terá evoluído durante as décadas de 30/40. Os Comoreanos era o local em que este grupo se encontrava para confraternizar. Pertença da Associação Beneficente Comoreana ${ }^{5}$, existiu até ao início da década de 40. Era bastante popular na zona suburbana, recebendo também gente da zona urbana que procurava diversão. Era também frequentado por marinheiros de passagem, portugueses entre outros europeus e outras nacionalidades. Como indivíduos que professavam a religião islâmica, os comoreanos criaram os seus locais de culto, nomeadamente as mesquitas Camaria (pedra), vulgarmente conhecida como Iti Faque (acordo), e Baraza (local de convívio) (Lemos, 1988: 53).

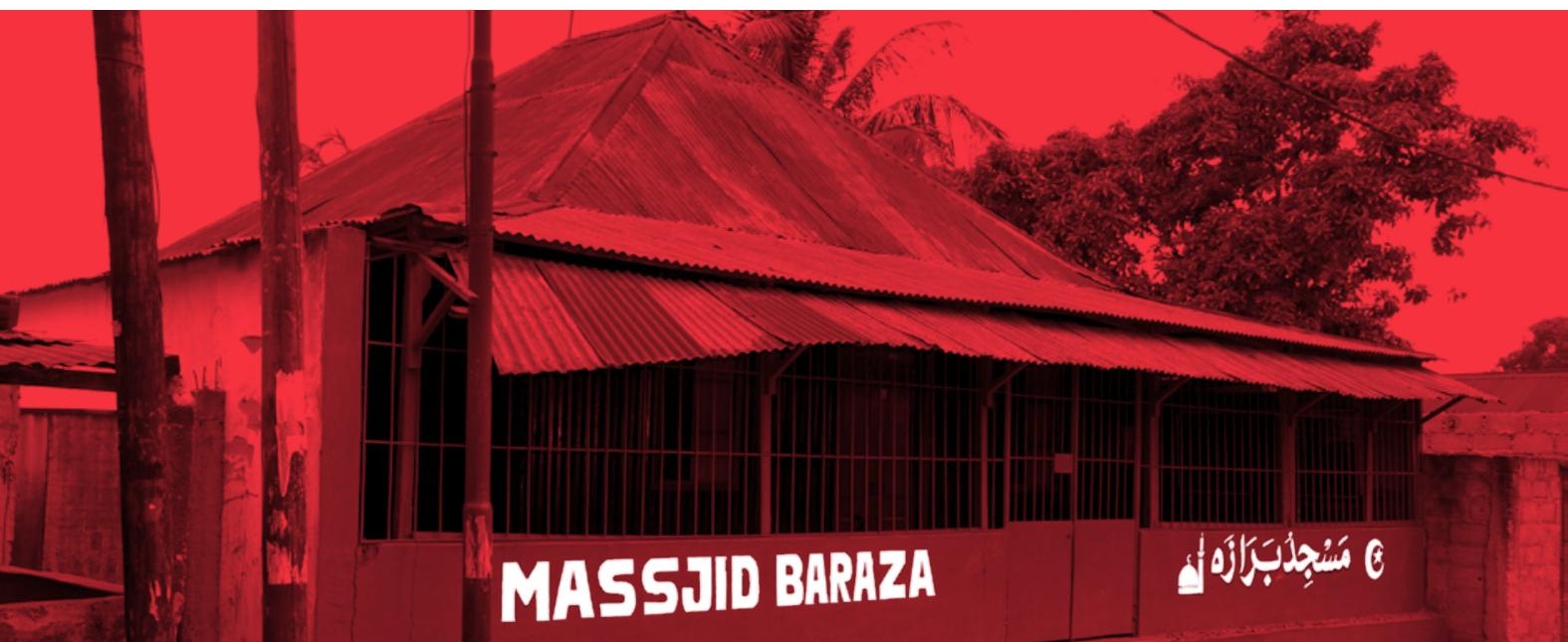


A maioria da população da Mafalala era negra: macuas, marongas ${ }^{6}$, machanganas $^{7}$ e em menor número os bitongas ${ }^{8}$. A convivência entre estes grupos era livre de qualquer preconceito, apesar de professarem religiões diferentes e provirem de diferentes culturas (por exemplo, os macuas eram muçulmanos e originários do norte de Moçambique). Como afirma Freitas:

\begin{abstract}
O indivíduo como ser social que é, sofre a influência do grupo em que se encontra integrado e a sua atitude é tanto mais pautada pelas formas de comportamento por este consideradas fundamentais, quanto mais com ele se encontra identificado. Por via de um conjunto de regras de conduta, costumes e maneiras de agir, os grupos exercem um controle social sobre os seus membros, controle que assegura a unidade grupal e garante relações ordenadas entre eles. (Freitas, 1965: 6)
\end{abstract}

É este controle social que os indivíduos destribalizados e urbanizados já não sofriam em virtude de se encontrarem distantes dos seus grupos sociais de origem. $\mathrm{O}$ abandono das suas terras de origem tinha razões diversas, que vão desde os motivos económicos e de procura de uma vida melhor à negação de pagamento do imposto da palhota, à tentativa de escapar ao chibalo, podendo também ter a ver com o lobolo9, que obrigava muitos homens a emigrar para conseguirem pagar o valor estipulado pela família da noiva. 


\section{A Mafalala na voz dos seus moradores}

Um aspeto a destacar na coabitação dos moradores da Mafalala é o facto de os diferentes grupos étnicos conviverem entre si e respeitarem as práticas culturais de cada um sem conflitos e imposições de espécie alguma, como provam os vários casamentos mistos que se verificaram entre os seus habitantes, reveladores da tolerância e da harmonia existentes $^{10}$. Sobre o processo de integração dos habitantes e hábitos quotidianos, temos o testemunho de Issulay Bino Hagy, 70 anos, morador da Mafalala, que nos diz:
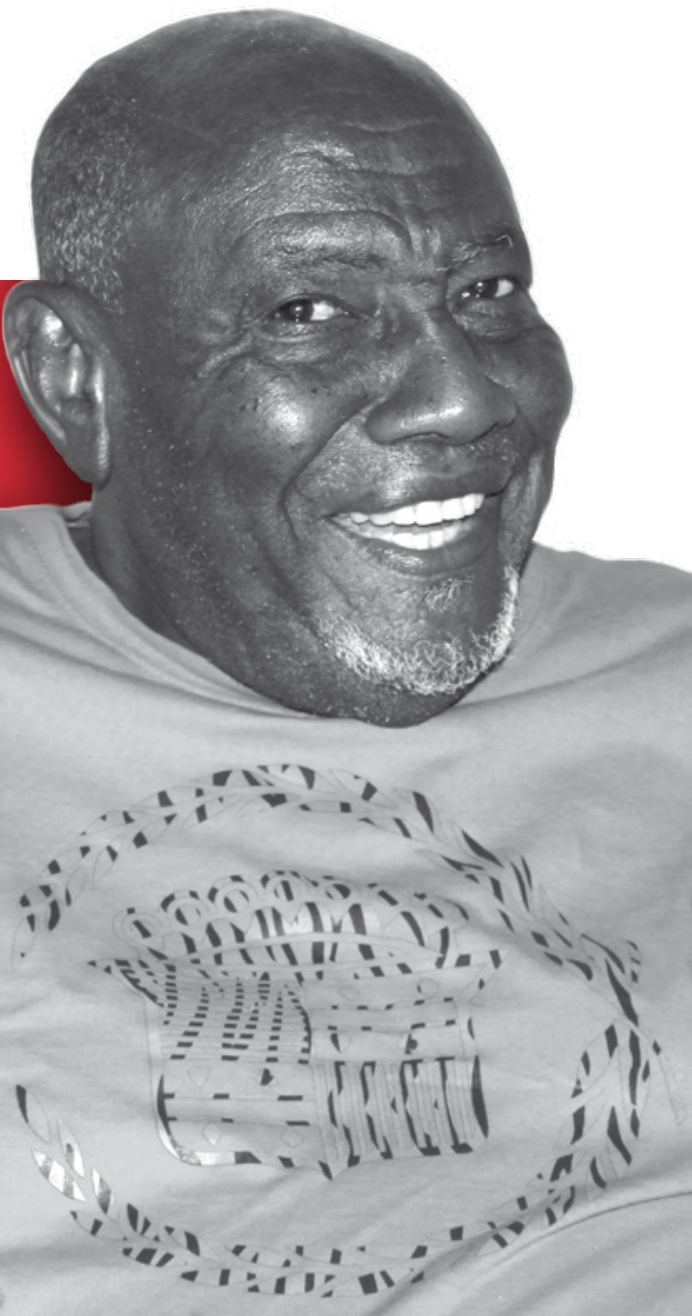
Meu pai era natural do arquipélago das Comores, Moroni, nascido em 1886, veio a Moçambique por volta de 1920. Morreu em 1955. Meu pai veio a Moçambique como aventureiro. De Moroni passou para Zanzibar, daí transitou para Moçambique num barco chamado Caranja que vinha das Ilhas. O meu pai veio a Moçambique à procura de melhores condições de vida, pois, a vida nas Comores era dura.

Conhece a minha mãe e casa-se, donde nascem seis filhos. Eu sou um dos últimos. Nós tínhamos um estatuto especial como filhos de cidadão francês, pois até no 14 de Julho éramos convidados ao consulado Francês para celebrar o dia de França. E sempre que uma fragata francesa aportasse em Lourenço Marques éramos também convidados. (Issulay Bino Hagy, 2014)

\section{Em relação à infância regista:}

Tive uma infância normal, convivia entre família, jogávamos aos berlindes, aos paulitos, que chamávamos já-já e depois tínhamos o nosso futebol, não jogámos com Eusébio, mas jogávamos entre nós os mais novos. Jogávamos com a bexiga de boi a que chamávamos Chihuhuto. Esta bexiga de boi era vendida por senhores que transportavam tripas em burros, os quais vinham até à cantina do Nunes. E a bexiga era comprada ali. Depois de seca era uma bola autêntica. Nos dias de vento não era nada bom, pois a bola era leve e voava com facilidade. E por mais que a enchêssemos esta não se rebentava. Não sei se o Eusébio chegou a jogar com esta bola, pois era mais velho, como disse. Para além do futebol, jogávamos às castanhas com uma lata de leite condensado Cruz Azul que chamávamos Xicotela. A Mafalala era uma zona cheia de árvores de fruta como cajueiros, mangueiras e palmeiras. Com o tempo estas foram desaparecendo devido ao desenvolvimento. E, quando saíamos da escola, ficávamos a jogar futebol, era dois muda e quatro ganha. Chegávamos tarde a casa, porque para termos um vencedor era difícil. O vencedor tinha que marcar quatro golos, o mais velho só podia chutar do meio campo dele para a baliza. Se ultrapassasse o meio campo já não podia chutar a baliza, tinha que fazer um passe ao colega de equipa.

Também jogávamos ao Din-Katlha com uma bola maluca. Nós éramos muito disciplinados. Se saíssemos às $20 \mathrm{~h}$ de casa para ir a uma festa de 


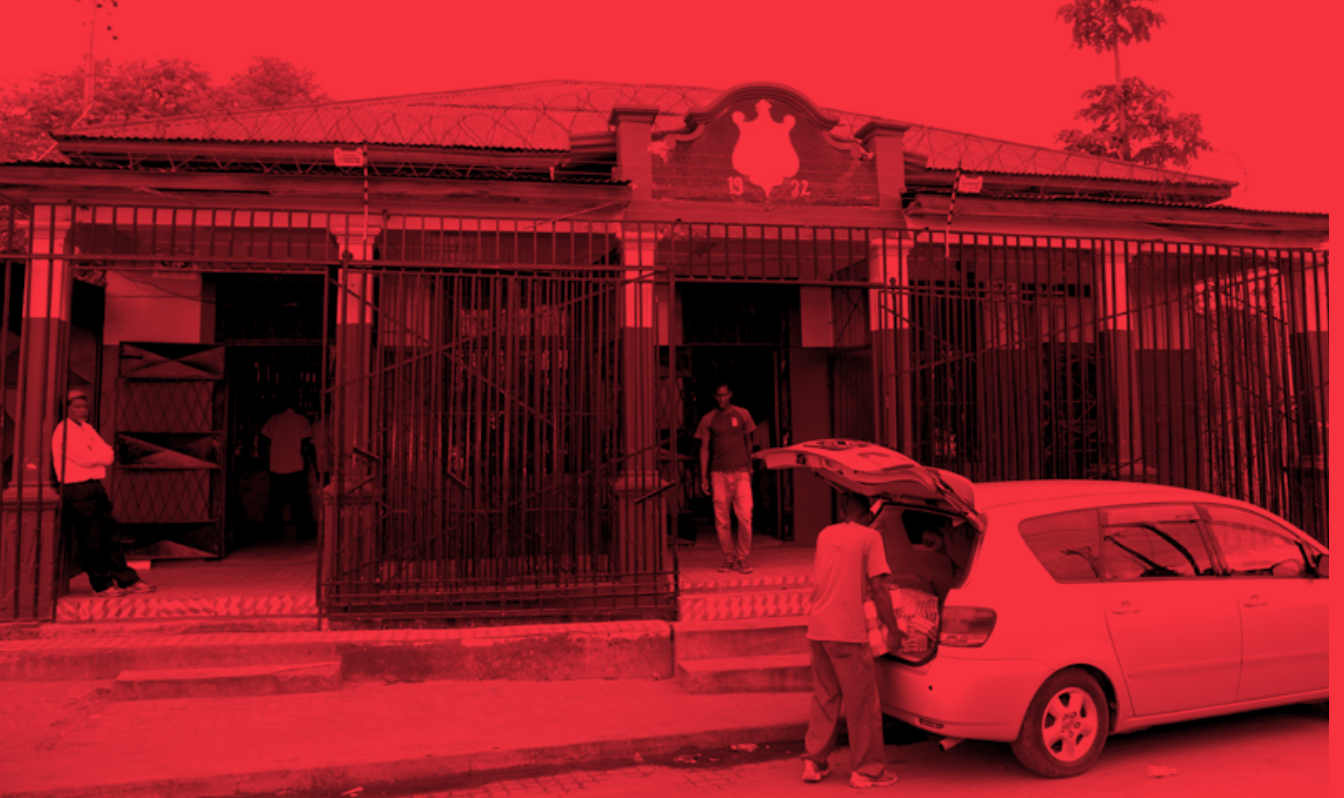

Cantina do Mufundisse, 2013.

Unce ${ }^{11}$ tínhamos que voltar às $24 \mathrm{~h}$ e tinha que ser mesmo àquela hora. Aqui viviam portugueses, cabo-verdianos e santomenses. Os Netos, os que tinham este apelido, eram descendentes de cabo-verdianos, estavam naquela zona do Mukumula12. Os santomenses desapareceram logo. Também havia brancos, a munhuana era o limite. Ali aonde está escrito largo da habitação; depois havia o largo João Albasini, aonde se encontrava uma grande comunidade de mestiços. Havia também chineses que tinham cantinas, caso do King, Boutima; estes chineses viviam nas lojas, marido e mulher. Todos estes foram-se embora. 0 único cantineiro que resistiu às mudanças foi o Mufundisse ${ }^{13}$, que terá instalado a sua cantina em 1932. Os que hoje ali se encontram devem ser os bisnetos. (Issulay Bino Hagy, 2014)

A partir deste depoimento podemos elaborar várias leituras sobre a forma de vida dos moradores da Mafalala, a maneira como circulavam e como eram as casas do bairro nos anos das suas infâncias.

Em relação à circulação da população indígena, ouçamos esta voz da Mafalala de novo:

Os nossos pais andavam na cidade até tarde por causa do cofió. E também havia o passe. Depois das 21h havia polícia. Tinha que ver se tinha o imposto em dia. Mas a nossa malta normalmente não ia 


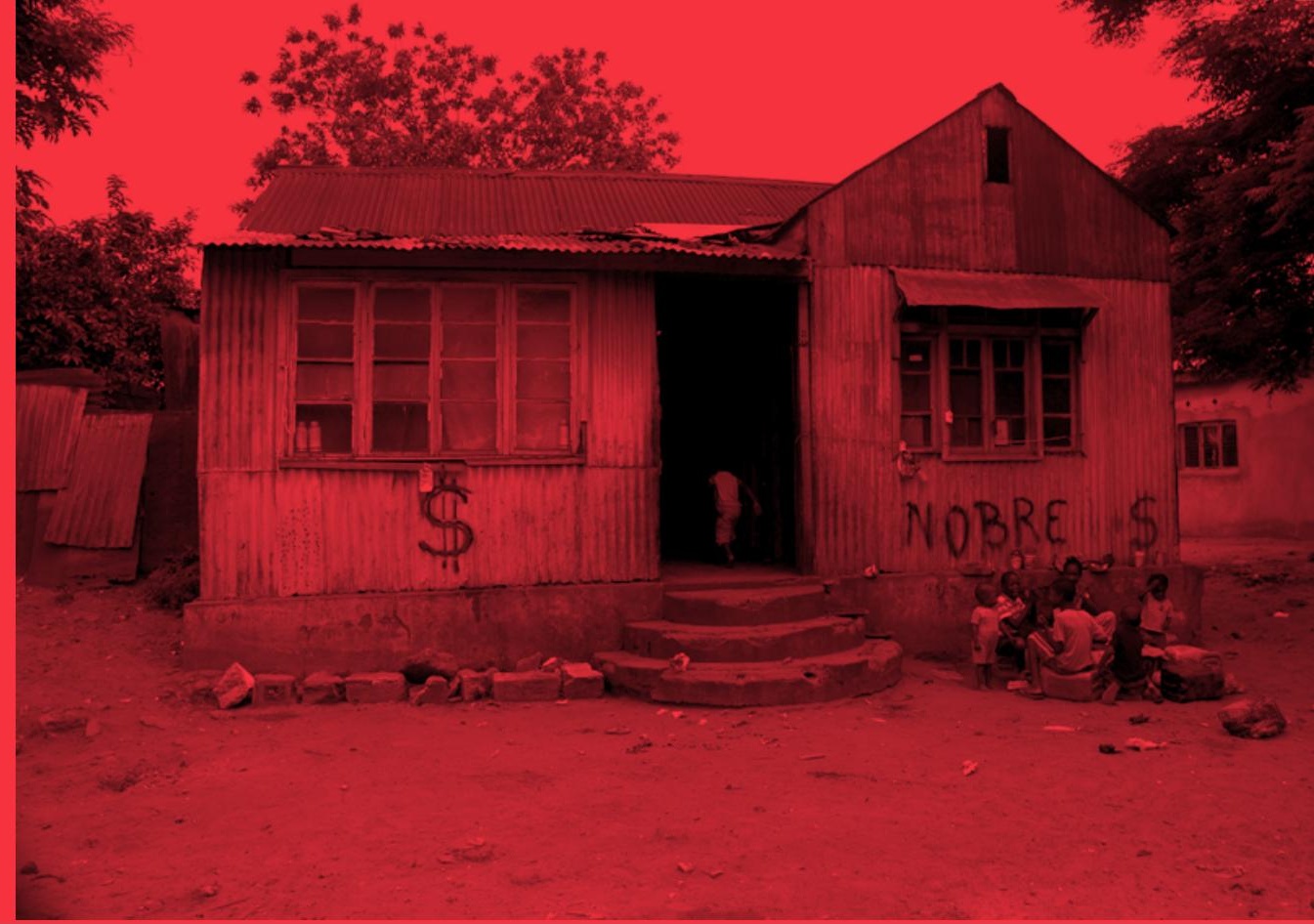

Exemplar do tipo de casa de madeira e zinco com multiplas àguas, 2013.

para longe. Tinha o Cinema Império, a cidade não nos interessava. Mas íamos quando havia a feira popular e o circo Baswell ali atrás do Avenida, no Pendra \& Sousa. Para a malta bastava ir ao Solar Familiar no Alto-Mahé, à Tijuca, no largo João Albasini. O único sítio aonde a malta ia com alguma frequência era o Piri-Piri, era um sítio aonde não se sentia a segregação. (Issulay Bino Hagy, 2014)

\section{Em relação às casas do bairro, os testemunhos são elucidativos:}

As casas eram de madeira e zinco e quem tivesse posses construía uma de duas águas. Normalmente com um quarto e sala. Mais águas sinal de maior posse. (Issulay Bino Hagy, 2014)

\section{Sobre os proprietários africanos diz-nos:}

Existiam proprietários africanos de terrenos como o caso do Samora Correia14, que era duro com os inquilinos, segundo alguns, o nome Mukumula terá sido originado por este senhor pelo facto de ao fazer as cobranças dizer ao inquilino que não pudesse pagar a mensalidade o seguinte: "kumula a hindlo dza ku u famba"15. (Issulay Bino Hagy, 2014) 
Nesta entrevista há ainda o interessante registo das mudanças que se verificaram no bairro, pois o nosso entrevistado foi viver para Moroni cerca de 20 anos. Quando regressou, diz-nos sobre as mudanças na Mafalala:

Quando regresso a Moçambique e volto para a minha Mafalala sofro um choque. Tudo tinha mudado, até a nossa casa entrava carro, agora não é possível, os amigos estão todos dispersos. Mas isto é o mal menor, o pior de tudo é a limpeza, agora praticamente não se faz limpeza. (Issulay Bino Hagy, 2014)

A partir do nosso entrevistado tem-se a perceção "viva e colorida" de como era a vida na Mafalala durante o período colonial assim como no pós-independência, apesar de este período não ser o foco dos excertos de entrevistas acima citadas.

Outro dos nossos entrevistados, Sebastião Madeira, diz-nos:

Nasci na Mafalala em 1953. Sou descendente dos Ndau ${ }^{16}$. O meu avô foi militar do Estado de Gaza, de Mudungazi, e participou no movimento migratório deste grupo de Manica para Mandlakazi17. O meu pai que é natural de Chibuto, vem para Lourenço Marques em 1926, e vem viver para a Mafalala em 1948. Para ganhar a vida teve que trabalhar como empregado doméstico. Como uma das melhores recordações do bairro tenho a solidariedade que existia entre nós na resolução dos problemas. (Sebastião Madeira, 2014)

Em vários depoimentos, é referida a importância do desporto como momento agregador das várias comunidades e da vida do bairro:

Naquela altura as duas melhores equipas da zona suburbana eram o Barcelona e os Brasileiros da Mafalala. Os jogos realizavam-se no Campo do Xipamanine. Nos Brasileiros estava Eusébio, Maló, Jeque, José da Broa e do lado do Barcelona eram os Miglietis. Estes dois bairros eram os principais da altura. Antes de se falar de unidade nacional, nós já tínhamos na Mafalala. Pois ali encontravam-se marongas, macuas, manhenbanas, alentejanos e mestiços. Vivíamos em perfeita harmonia. É difícil dizer que havia conflitos entre nós. 


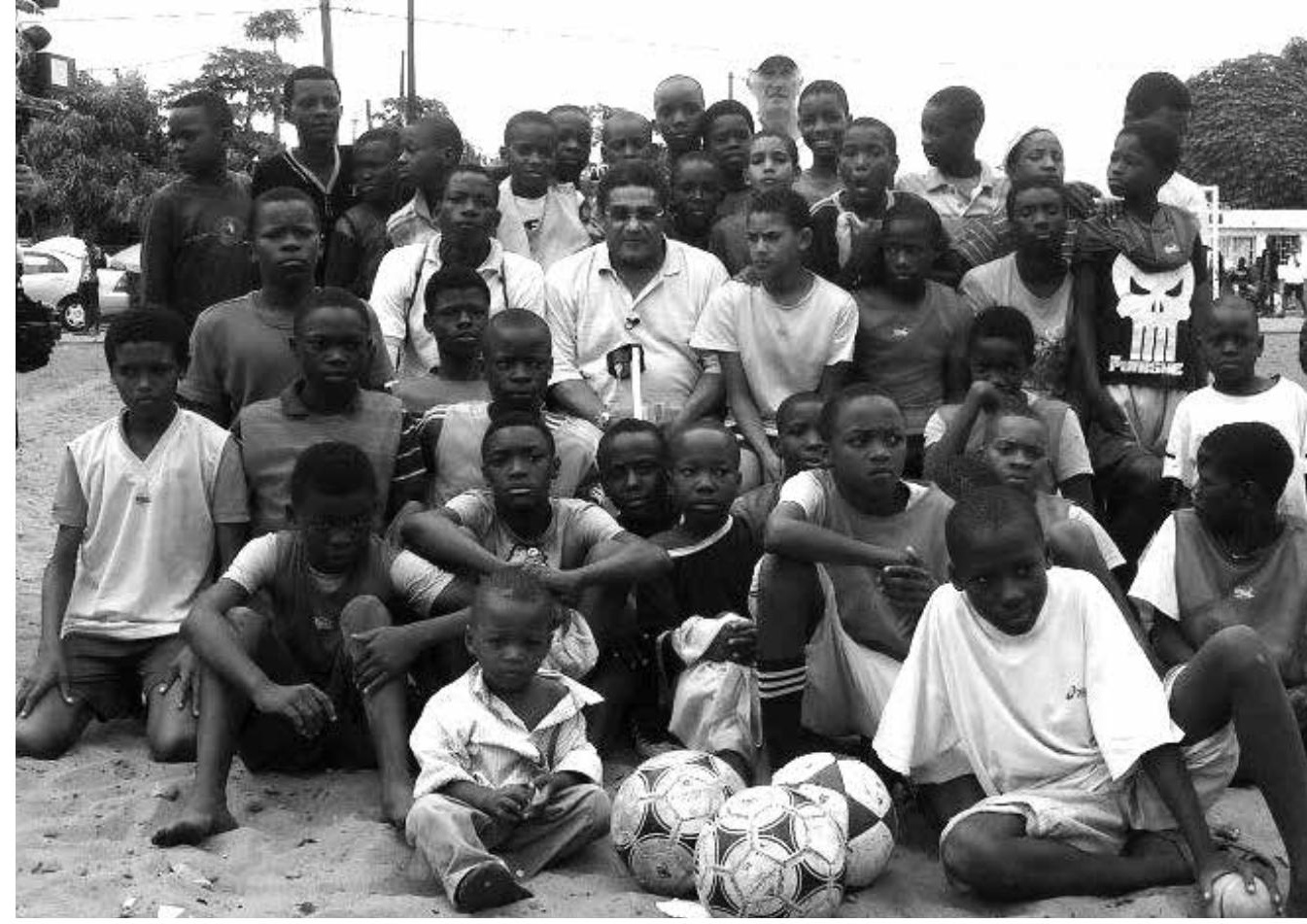

Eusébio da Silva Ferreira: última visita ao bairro, 2013.

Este espírito leva à criação do Munhuanense Azar, clube dos mafalalenses, por mulatos e negros. O Munhuanense surge da dissidência de alguns elementos que saem do Clube João Albasini.

Seria muito importante tecer algumas considerações sobre a importância das associações e das associações desportivas na construção da unidade nacional que levou à luta e na perceção da diferença relativamente àquilo que era definido como Moçambique pelo regime colonial.

(Sebastião Madeira, 2014)

Nesta entrevista vale a pena ouvir também as opiniões tecidas relativamente ao ordenamento urbano no tempo colonial:

Os portugueses não permitiam que construíssemos casas de carácter definitivo, estas tinham que ser de caniço, madeira e zinco e maticada. Isto era assim porque aqueles terrenos tinham dono, o terreno aonde está a casa construída pelo meu pai, por exemplo, era da Casa Coimbra. (Sebastião Madeira, 2014)

O estudo elaborado pelo Centro de Estudos de Desenvolvimento do Habitat da Universidade Eduardo Mondlane (CEDH-UEM), em 2006, 
sobre assentamentos informais e o projeto de urbanização da zona suburbana fornece-nos vários dados sobre esta realidade. O estudo diz-nos que, nos primórdios dos anos 70 e no auge da guerra de libertação, as áreas suburbanas de Lourenço Marques albergavam 4/5 da população total da cidade, estimada em 600.000 habitantes. O subúrbio era então visto pelas autoridades como o viveiro onde floresciam os ideais da revolução e do ódio ao regime. Assim, e de forma a se ganharem as "mentes e corações" dos habitantes daquelas áreas, na linha da chamada "política da psico", tornou-se urgente iniciar ações de melhoria do nível de vida dos habitantes. Vejamos a seguinte citação:

O estudo para a resolução dos problemas emergentes da ocupação indisciplinada de zonas suburbanas, originada pelo constante afluxo da população rural à cidade, tem vindo a merecer especial atenção por parte da administração. Nisto, e por determinação de S. Exa. o senhor Governador-Geral, em reunião efetuada a 25 de Julho de 1970, no GUHARLM, e estando presentes os Exmos. Senhores Secretários Provincial das Obras Públicas, Presidente da Câmara de Lourenço Marques e o Director do Gabinete de Urbanização e Habitação da Região de Lourenço Marques (GUHARLM), foi decidido iniciar-se o estudo de remodelação de uma zona de caniço, numa faixa compreendendo a então Craveiro Lopes, o aeroporto e a cidade de cimento. (CEDH-UEM, 2006: 15-16)

O resultado evidente da ação do GUHARLM na Mafalala foram as escolas. Neste caso, a Unidade 22 e 23 apresentam infraestruturas que refletem os objetivos da criação deste gabinete, nomeadamente pela construção de um campo de jogos e uma piscina, o que para a zona suburbana era impensável.

Continuando na análise da Mafalala a partir dos depoimentos dos seus habitantes, ouçamos Roberto Machava, que chegou à Mafalala ainda no período colonial e aqui viveu a independência, que malogradamente Ihe trouxe o fim do negócio:

Eu cheguei a Maputo vindo de Gaza e comecei a trabalhar como empregado doméstico, mas depois criei o meu próprio negócio. 
Criei uma lavandaria em casa aonde lavava e engomava a roupa das pessoas do bairro. Tinha quatro empregados. As pessoas que queriam ver a sua roupa bem passada e engomada procuravam por mim. Até tinha clientes brancos. Não tinha tempo para descansar.

Com a independência o meu negócio desapareceu. Pois, quando se dá a independência os novos dirigentes começaram a dizer que não se podia praticar o negócio privado e reuniram todos aqueles que se dedicavam ao negócio de lavandaria num recinto na Machava, com uma gestão coletiva, acabei desistindo porque não estava a ver o resultado do meu trabalho. Desta maneira terminei com o negócio. (Roberto Machava, 2014)

\section{Em relação à sua vida lamenta:}

Olha a minha vida piorou muito nestes últimos anos. Naquele tempo eu tinha os meus negócios como disse. Tinha a lavandaria e tinha duas casas que alugava, mas com a independência isso tudo acabou e hoje sou um guarda noturno. E com o dinheiro que recebo não dá para fazer nada. As coisas pioraram bastante. (Roberto Machava, 2014)

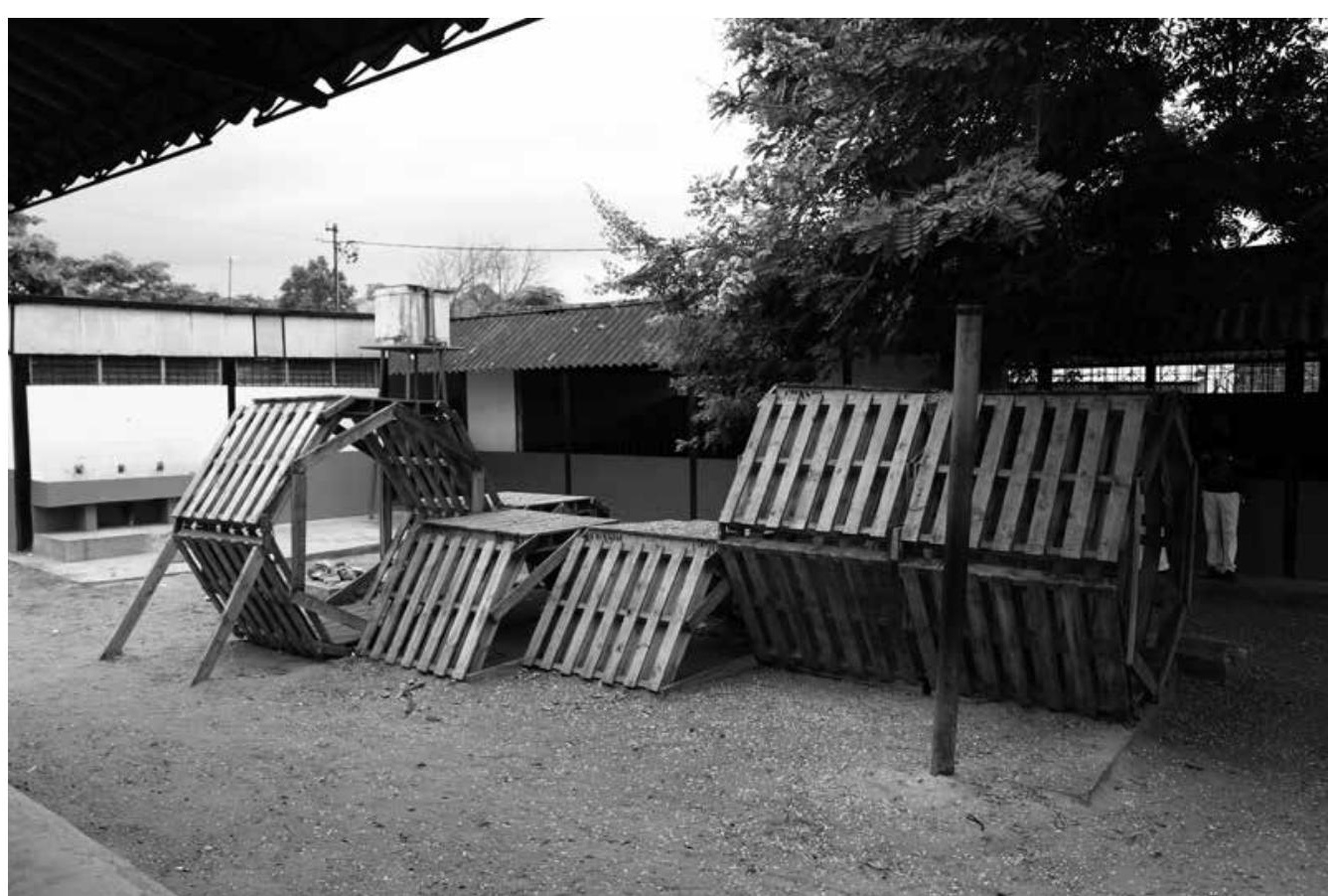




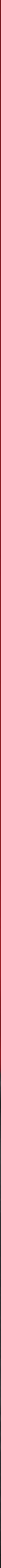




\section{Um outro habitante Shehe ${ }^{18}$, Cássimo David, associa a vida do bairro à ação cultural de afirmação das várias comunidades aí existentes, com as suas diferentes etnias, línguas e religiões:}

Nasci em 1957, em Maputo, e sempre vivi na Mafalala. Meu pai era natural de Inhambane e vivia no bairro de Minkadjuíne ${ }^{19}$ e a minha mãe era daqui. Devido ao casamento, a minha mãe converteu-se ao Islamismo. Tive uma infância normal como as outras crianças. Enquanto crescia joguei muito futebol, dancei tufo, nzope, marrabenta, etc. Já na fase adulta fiz parte do grupo Unce da Mafalala que até hoje existe. Tocávamos em festas, casamentos, até em festas de membros do partido. O grupo abrilhantava as festas na zona suburbana. Pela banda passaram várias pessoas, nomeadamente: Abdul Razak, CocaCola ${ }^{20}$ (Issufo), Abdala Mubarak, falecido Ibrahimo, Muhamad Hagi, falecido Daúde, Kadir, Abdul Raúfo, meu irmão, velho Issufo (Two batata) ${ }^{21}$, que era o nosso maestro, era ele que nos fazia as letras. E, entre as senhoras, destaco: Maimuna, Camaria, Laila, Albertina, Fatiminha, Aziza e muitos outros. Esta banda fez furor.

A banda foi fundada um pouco antes da independência e as letras eram na sua maioria de Juma Mukhatsika, esse grande poeta da língua ronga. Ele escreveu letras e canções lindíssimas inspiradas no dia a dia. Comparando o unce à marrabenta diria que esta era para todos, enquanto que o unce era específico, era de origem árabe, não era para todos. Mas ficou popular porque misturamos com marrabenta, n'fena. O unce original não era mexido, nós é que revolucionámos, misturámos com rumba, marrabenta, etc. Não tínhamos fim de semana livre, quem se casasse requeria a nossa presença. Nos dias nacionais tocávamos no círculo. Considero o Juma Mukhatsika um dos maiores poetas da língua ronga, pois ele compôs músicas de unce de grande valor. A maior parte das músicas deste género musical tocadas e cantadas até hoje são da sua autoria. (Cássimo David, 2014) 
A mudança radical de atitude ocorre apenas nas décadas de 1960 e 70, em virtude da emergência dos movimentos independentistas em África. Assim, Portugal vê-se obrigado a adotar uma política de aproximação e integração através da produção de um discurso de diálogo ecuménico, que se intensifica a partir do início da luta armada de libertação nacional liderada pela FRELIMO (Silva, 2009: 6). Julgamos, portanto, que neste contexto se encontram os fatores que estiveram por detrás da menor divulgação e popularização do unce, dado tratar-se de uma prática cultural muçulmana e, portanto, vigiada durante muito tempo, em oposição à marrabenta, que, exibindo valores culturais africanos e ocidentais, se tornou popular.

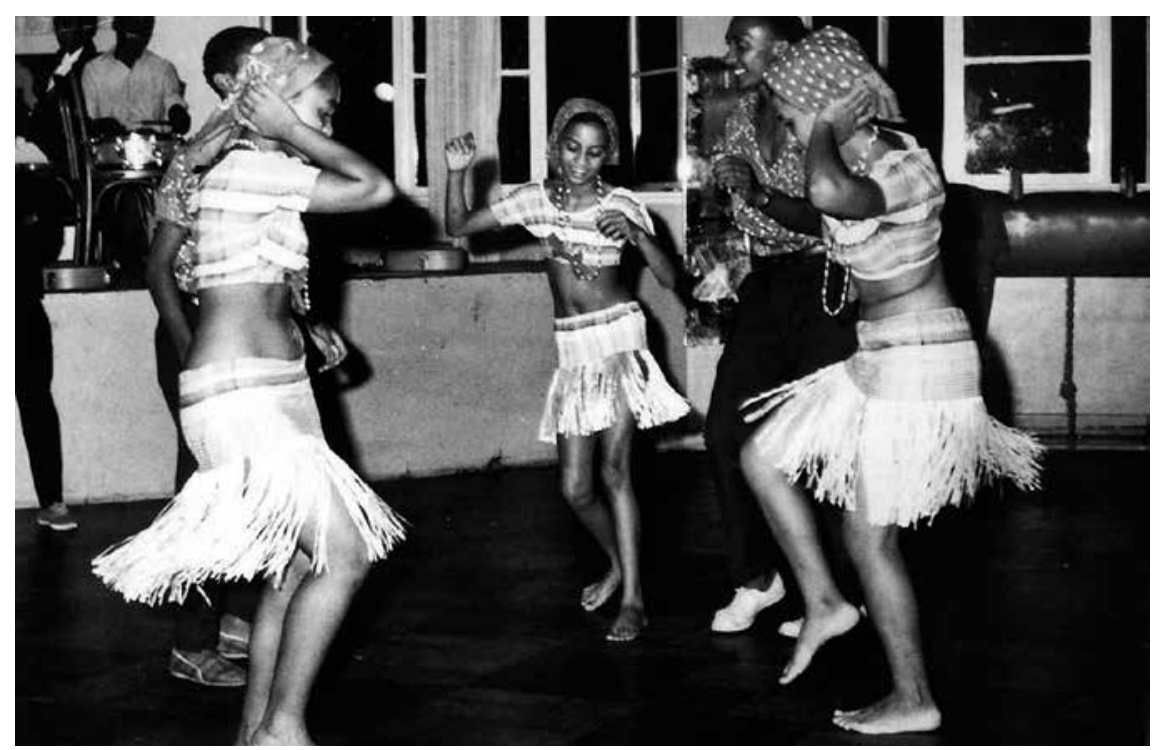

Dançarinas de marrabenta, década de 1950.

Retomando a entrevista anterior, muitos são os dados revelados que apontam para a importância das práticas desportivas na construção da identidade do bairro e da tolerância, bem como na formação de uma consciência política.

Como desportista joguei futebol nos juniores do Benfica de Nampula, aonde, em 1969, sagramo-nos campeões sem termos ganho um único jogo em campo, devido à falsificação de idades pelas equipas 
do Sporting e Ferroviário ao longo do campeonato. No ano seguinte voltámos a ganhar o campeonato provincial, hoje nacional, em jogo jogado. Julgo que fui um jogador talentoso, pois cheguei a ter uma proposta para jogar no Benfica de Portugal, mas o meu pai recusou-se a aceitar a proposta, porque julgava que como muçulmano que era podia ficar influenciado pelo modo de vida ocidental, também fiz parte da seleção da Mafalala de forma regular. De notar que havia jogadores de grande nível, mas era sempre um dos primeiros a ser escolhido e isso enchia-me de orgulho. Com esta seleção fomos ganhar o campeonato no Xipamanine.

As pessoas do bairro eram unidas apesar de provirem de diferentes províncias do país. Até os mabandidos ${ }^{22}$, quando passassem pelo nosso bairro, tinham mais cuidado porque estávamos de tal modo organizados que se fizessem algum mal a um morador da Mafalala tinham uma resposta à altura. As pessoas viviam em harmonia. Mesmo em termos religiosos a tolerância era mantida, é o meu caso. Tenho família pelo lado da minha mãe que é católica, as minhas tias e, do lado do meu pai, muçulmanos, portanto, os casamentos ajudaram a manter o bom relacionamento e a tolerância entre pessoas e famílias de diferentes credos religiosos.

Outro momento que serviu para mostrar a solidariedade existente entre os habitantes do bairro foi o 7 de setembro de 1974. Eu entrei para a tropa em março de 1974 e saio em 1975. Quando começa a agitação em resultado da confirmação da independência nacional peço uma dispensa no quartel para vir para casa e ajudar na defesa do bairro. O quartel-general foi em casa dos Calianos. Fizemos questão de proteger as lojas. Nós que estávamos na tropa usámos as armas e munições para proteger o bairro. A proteção que fizemos às lojas ajudou bastante quando começou a haver falta de mantimentos, pois os habitantes de outros bairros não tinham tido a mesma preocupação, tinham saqueado as lojas.

Existe uma ideia de que só é nacionalista quem foi à Tanzânia, isso não é verdade. Tivemos aqui nacionalistas de primeira hora como o Issufo Museraji, Yussuf Aboobakar. Políticos que arrastaram e abriram a cabeça de muita gente. Há também o Nuno Caliano, Sr. Pais, outros nacionalistas de primeira hora que não lutavam só pela independência de Moçambique, mas pela região. São estas figuras que precisam 
de ser lembradas porque fizeram algo pelo país, com as limitações impostas pelo sistema colonial, procuraram veicular a necessidade de independência e liberdade de Moçambique e de outros povos africanos. (Mussa Ibrahimo, 2013)

\section{Também Issufo Aly, nascido na Mafalala, nos confirma, de outro modo, as ideias expostas pelo último entrevistado:}

O meu pai era natural da llha de Moçambique, veio trabalhar como marceneiro no Paulino Santos Gil23. Primeiro veio o seu irmão que trabalhou lá e chamou o meu pai. O meu pai trabalhou muitos anos no Santos Gil. Eles faziam as rodas das carroças. O Paulino Santos Gil localizava-se na atual Escola Secundária Estrela Vermelha (Joaquim de Araújo). Ali era a lixeira. Ali aonde está o atual Dumba Nengue do Estrela Vermelha não havia nada, só existia um canhueiro e a gente jogava futebol ali. Aquele espaço estendia-se até à Marien N'Gouabi (Caldas Xavier). A esquadra não existia. Isto tudo era mato, até havia caça de perdizes e patos, aqui na zona do Shoprite, nas famosas lagoas. E nós é que apanhávamos os animais abatidos pelos portugueses. A Malhangalene ainda não existia, tinha algumas casas. Isto era mato cerrado. Se você saísse para lá sozinho era capaz de voltar de medo, dado o mato que havia. Isto por volta de 1942, tinha os meus 7 ou 8 anos.

Nasci na Mafalala em 1935 e, durante a minha fase de crescimento pratiquei desporto, sobretudo futebol. Regra geral, o pessoal da Mafalala era do Munhuanense Azar ou do João Albasini. O pessoal que vivia na zona do Gato Preto ${ }^{24}$ até aos Calianos e subindo até a Avenida de Angola é que era do Munhuanense. Os que viviam entre o Rodrigues e o Mufundisse era malta do João Albasini, mas estavam sempre juntos sem problemas. A rivalidade era só no campo. Havia também adeptos do Mahafil Isslamo e do Atlético Maometano. Nestes campeonatos jogava-se futebol a sério. Um jogo entre o Beira Mar e Atlético Maometano ou Munhuanense Azar e São José era bem disputado e arrastava multidões como já não se vê agora nos jogos do Moçambola25. (Issufo Aly, 2014) 
a)

Siln:

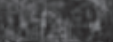

Non

$\rightarrow \operatorname{lat}^{2}$

3

$\therefore \geqslant$

$+3$

$12:$

13

1.

$-1$

1.:

:

(x)

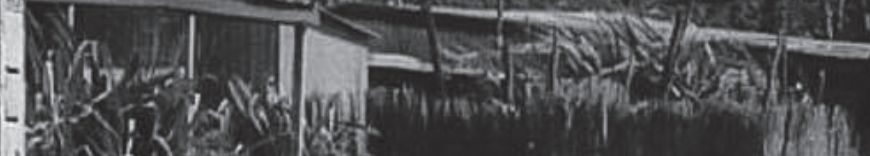

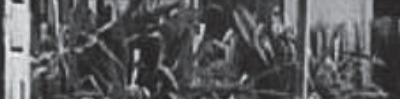
(2) $x^{2}$ a 150 (15) (15)

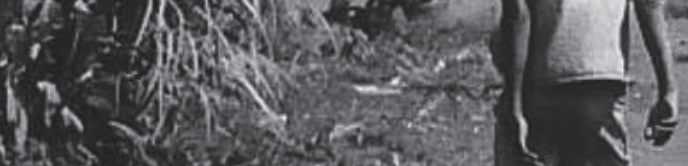

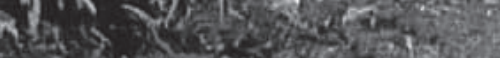

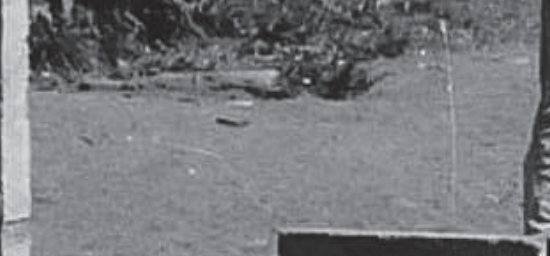




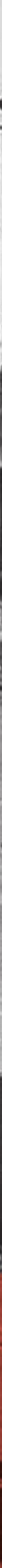


É importante frisar que as equipas africanas estavam filiadas à Associação de Futebol Africana (AFA), constituindo deste modo a 2. ${ }^{a}$ divisão. A 1. ${ }^{a}$ divisão estava reservada às equipas portuguesas que se encontravam filiadas à Associação de Futebol de Lourenço Marques (AFLM). Esta situação resultava das políticas segregacionistas impostas pelo estado colonial português. Como afirma Domingos (2009: 90), a AFLM, fundada em 1922, juntava clubes fundados por colonos, onde os jogadores negros e mestiços eram poucos. A AFA, por seu turno, foi fundada em 1924 e até 1959 organizou campeonatos com equipas dos subúrbios da cidade. Estes campeonatos eram compostos por equipas como o Beira-Mar, o Mahafil Isslamo, o Munhuanense Azar, o João Albasini, o Vitória Gazense, o Zambeziano, o Inhambanense, o Atlético Mahometano, o Vasco da Gama, o São José, o Nova Aliança e o Sport Nacional Africano.

Os dirigentes destes clubes eram na sua maioria assimilados, enquanto os jogadores eram indígenas. Esta fase corresponde ao período em

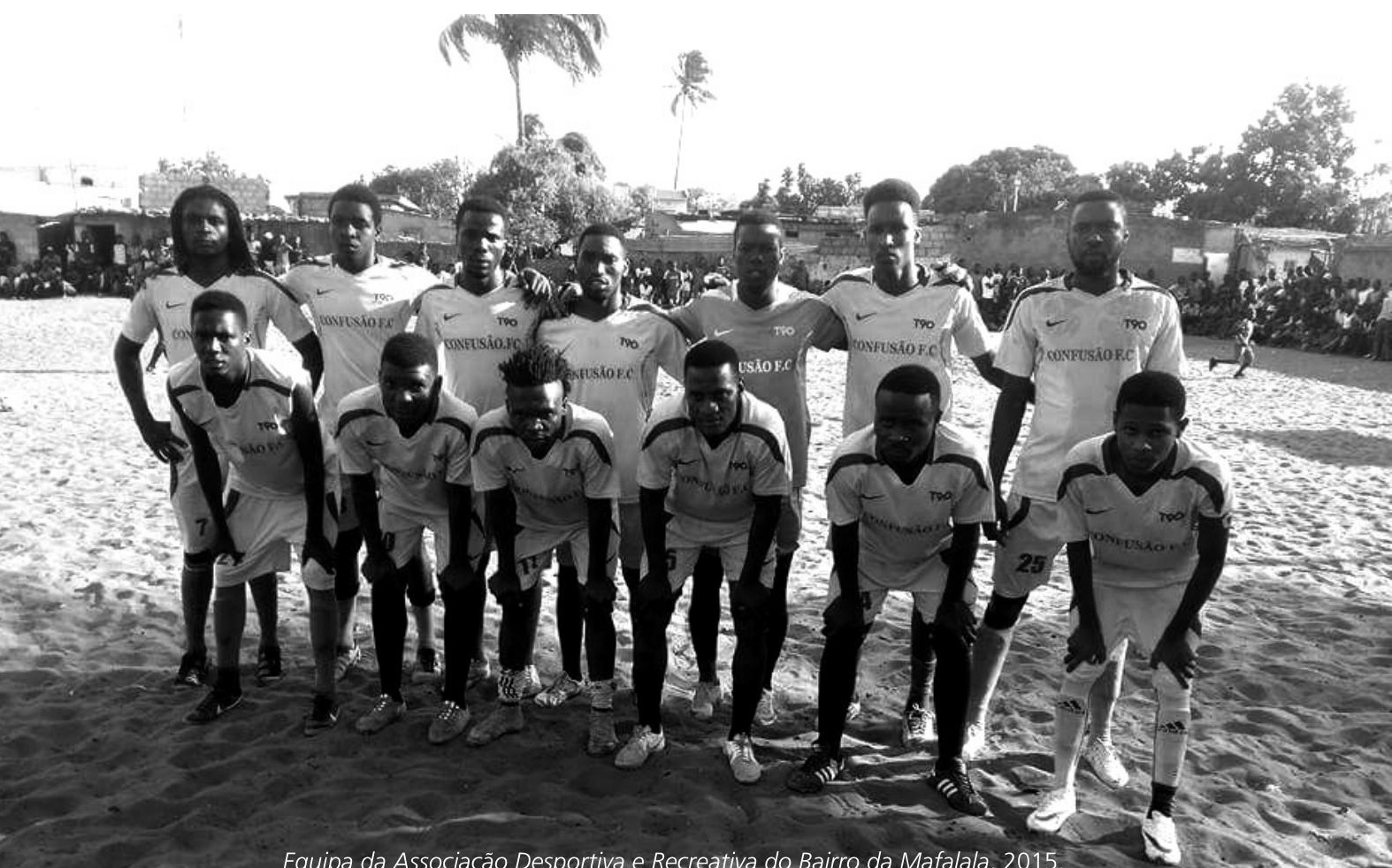


que o estado colonial português punha em prática as suas políticas segregacionistas. Mas já no final da década de 1950 começa a haver alterações na política colonial, em virtude das pressões internacionais sofridas pelo regime em relação à descolonização (Domingos, 2009: 90). Em 1952, dois clubes, o Vasco da Gama e o Atlético de Lourenço Marques, são integrados na AFLM e, de acordo com Domingos (2009), esta medida tinha em vista conquistar as elites mestiças que se encontravam à frente daquelas agremiações, que anteriormente tinham feito parte da AFA.

A AFA é abolida em 1959 e os seus clubes integrados no campeonato da 3. ${ }^{a}$ divisão da AFLM. A medida tinha como propósito o fim formal da discriminação racial no desporto, mas ainda sim, durante algum tempo, o vencedor deste campeonato não ascendia à divisão seguinte. Ainda no prosseguimento desta medida, os clubes africanos tiveram que eliminar dos seus estatutos as palavras discriminatórias, embora estas tivessem surgido em reação à discriminação racial. Foi apenas com a abolição do indigenato, em 1961, que a circulação de jogadores negros pelos clubes de Lourenço Marques fundados por colonos se tornou mais comum. Este fenómeno foi acompanhado pela maior abertura destes clubes a associados negros (Domingos, 2009: 98).

Nesta linha, em 1960, é instituída a medalha de mérito desportivo pelo Ministro da Educação Pinto Leite, como forma de nacionalizar e politizar as vitórias desportivas, úteis sobretudo quando projetavam o nome de Portugal. No contexto colonial, as participações de jogadores de origem africana como Coluna, Eusébio, Hilário e Vicente serviram para apoiar a teoria lusotropicalista de Gilberto Freyre, que considerava a colonização portuguesa única pelo seu suposto carácter miscigenador (Domingos, 2009: 96).

Porém, a realidade do sistema colonial era diferente, como nos mostra o depoimento de Issufo Aly, falando-nos da cobrança do imposto e do poder político e repressivo colonial:

O imposto era pago anualmente e era obrigatório. O valor a pagar era 50 escudos. Ferraz de Freitas, malalanhana ${ }^{26}$ era o administrador do concelho de Lourenço Marques e era muito temido. Era mau! Quem não pagasse o imposto ou cometesse alguma infração arriscava-se a apanhar com a "menina dos cinco olhos" (palmatória). Foi ele que 
criou as associações profissionais e os bailes que ali aconteciam.

A Mafalala era uma zona com areia solta, mas com o aumento populacional a água deixou de ter os seus caminhos e passou a haver inundações. Não era assim como é hoje. Com a independência começou a chegar mais gente ao bairro. Mas o pior momento, que contribuiu para a desordem atual, foi a guerra dos 16 anos. Com a guerra, os chefes de quarteirão e os chefes dos grupos dinamizadores venderam espaços para os deslocados, para os que fugiam da guerra. De modo que o bairro hoje apresenta este aspeto desordenado. (Issufo Aly, 2014)

\section{Voltando ao tempo colonial, o nosso entrevistado fala-nos da distribuição territorial, dos grupos e da vivência cultural do bairro nos espaços de diversão, nos meios de socialização, dos valores morais veiculados e dos aspetos políticos associados:}

Os macuas começavam no Rodrigues, até aqui na zona do Abdul Remane. Ao longo deste espaço havia também os mujojos. Havia também a zona do Gato Preto onde viviam os mulatos.

Os mestiços iam à Associação Africana e nós os negros íamos ao Centro Associativo dos Negros. O Centro enchia, parecia pequeno de tão cheio. Íamos ver o maestro Samuel Dabula e a Orquestra Djambo, íamos - a população negra - ao cinema Império, localizado na Avenida de Angola, por ser mais barato. Quem quisesse ou gostasse de filmes indianos tinha o Varietá na baixa. Os cinemas Gil Vicente e Scala estavam reservados aos brancos e assimilados, quem não fizesse parte deste grupo não entrava. Houve degradação dos valores morais. Naquele tempo havia regra, disciplina e autoridade, agora nada. Os jovens não te respeitam!

[Na época] começámos a ser vigiados pela polícia devido aos movimentos independentistas nos países africanos. Os portugueses diziam que nós seríamos os futuros presidentes. Tive que fugir de Chibuto para Magude, porque a PIDE vigiava-nos. Eu tinha para aí 27 ou 28 anos, isto por volta de 1962/63. Mas eu não tinha nada a ver com a política. E fujo destes sítios para Lourenço Marques. (Issufo Aly, 2014) 



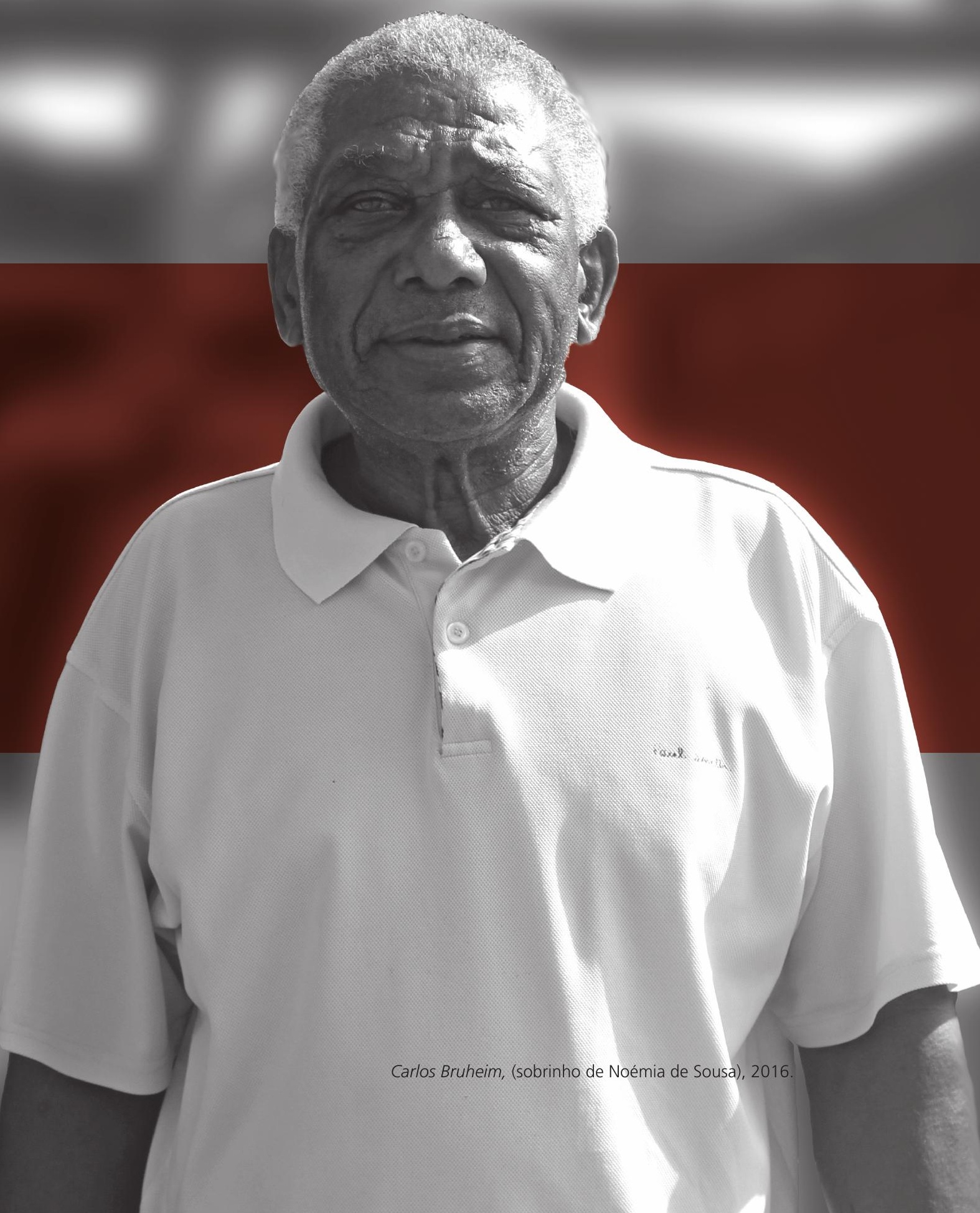


Por seu turno, Carlos Bruheim, outro habitante da Mafalala, revela-nos a teia de relações familiares que aí se traçavam a partir da sua família, o que nos permite ver o mosaico que é a Mafalala como um pequeno quadro da multiculturalidade moçambicana. Diz-nos:

Nasci a 10 de novembro de 1943 na Mafalala. Sou descendente de Alemães. O meu bisavô foi oficial do exército alemão que pediu asilo ao governo português e atribuiu-Ihe um sítio na Catembe. Chega fugido da Primeira Guerra Mundial. Uma vez estabelecido na Catembe teve filhos - com duas irmãs, que faziam parte da família real Tembe - um deles o meu avô. Segundo a história, o meu avô vem para Lourenço Marques devido a questões de proximidade, dado que queria que os seus filhos continuassem a estudar. Assim, a Mafalala surge como um dos locais com condições para que os filhos continuassem com os estudos. A sua chegada à Mafalala verifica-se por volta de 1907. O meu avô era despachante oficial com escritório na Rua da Gávea, hoje Rua da Catembe. Portanto, os filhos do meu avô eram: Ernesto e Carlos Bruheim, meus tios, e meu pai Francisco Bruheim. Do lado materno tenho a minha bisavó natural da Catembe, e os meus bisavô e avô goeses, naturais da antiga Índia portuguesa, de Damão.

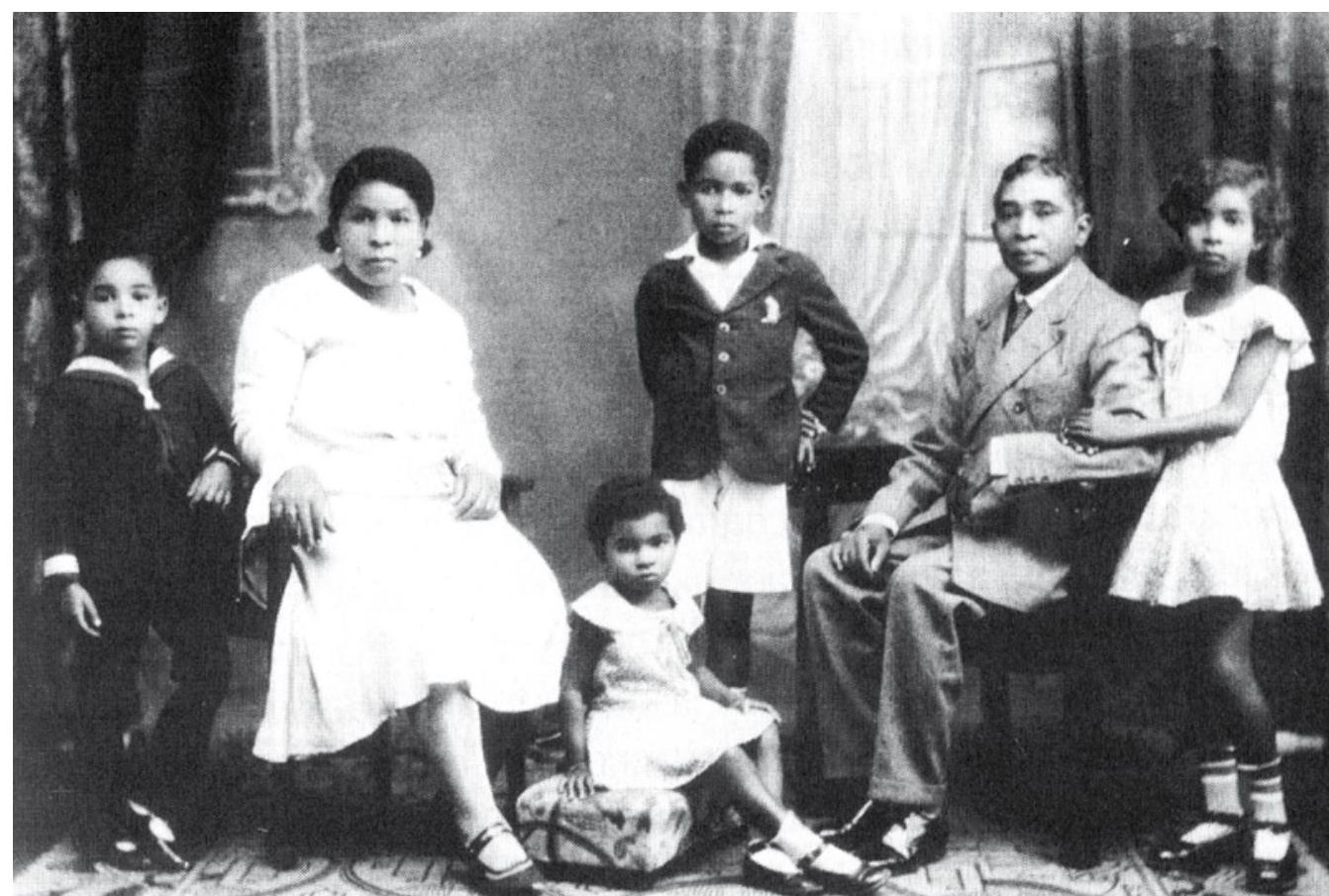


Estes eram comerciantes, estabeleceram-se na Mafalala e nunca mais saíram. A minha avó Clara Bruheim é a mãe da Noémia de Sousa, Nunes Abranches de Sousa e llda Bruheim, que é a mãe dos Albasinis: Biatriz Albasini, Ivo Garrido, Sérgio Albasini e João Luís Albasini. Passaram a ser Albasini porque a minha tia-avó casou-se com um Albasini. A Noémia de Sousa é minha prima devido a estas ligações familiares. Ela vem viver para a Mafalala entre 1938/9 e só sai em 1949 por motivos políticos. Ela, em pleno julgamento, engoliu a lista que tinha os nomes dos amigos que partilhavam os mesmos ideais que ela. (Carlos Bruheim, 2013)

\section{Neste depoimento, e para complexificar o mosaico familiar apresentado, são importantes as declarações do entrevistado relativamente à discriminação racial, em vários registos:}

Lembro-me de um episódio que aconteceu no casamento do meu primo Augusto Nogueira Sousa, que era considerado branco pela sua aparência e que ocupava a posição de Secretário Provincial do Governo Português em Lourenço Marques. Ele casou-se e convidou os tios e avôs que viviam no subúrbio. O copo de água realizou-se na Casa das Beiras, atual Instituto Nacional do Audiovisual e Cinema (INAC), mas à entrada encontravam-se porteiros brancos e um dos meus tios, o Lino Albano de Castro, era negro, quando chega a sua vez de entrar não lhe deixam por questões raciais. A sua sorte foi o facto de alguém próximo ter presenciado esta situação e informado ao meu primo que imediatamente se deslocou à entrada e fê-lo entrar contra os protestos do porteiro, que alegava que a festa era só para brancos e que ele não devia entrar. Este é um dos vários episódios que vivi e presenciei. Outro tinha a ver com a postura camarária nos transportes públicos, aonde os negros tinham que viajar em pé ou sentados na zona traseira do machimbombo. (Carlos Bruheim, 2013)

\section{Sobre os cantineiros diz-nos:}

Eram na sua maioria considerados brancos de terceira. Estes ajudavam-nos bastante, porque podíamos levantar os produtos a crédito. Tínhamos uma caderneta aonde anotávamos tudo o que levávamos e acontecia com frequência no final do mês termos um valor que excedia o que 


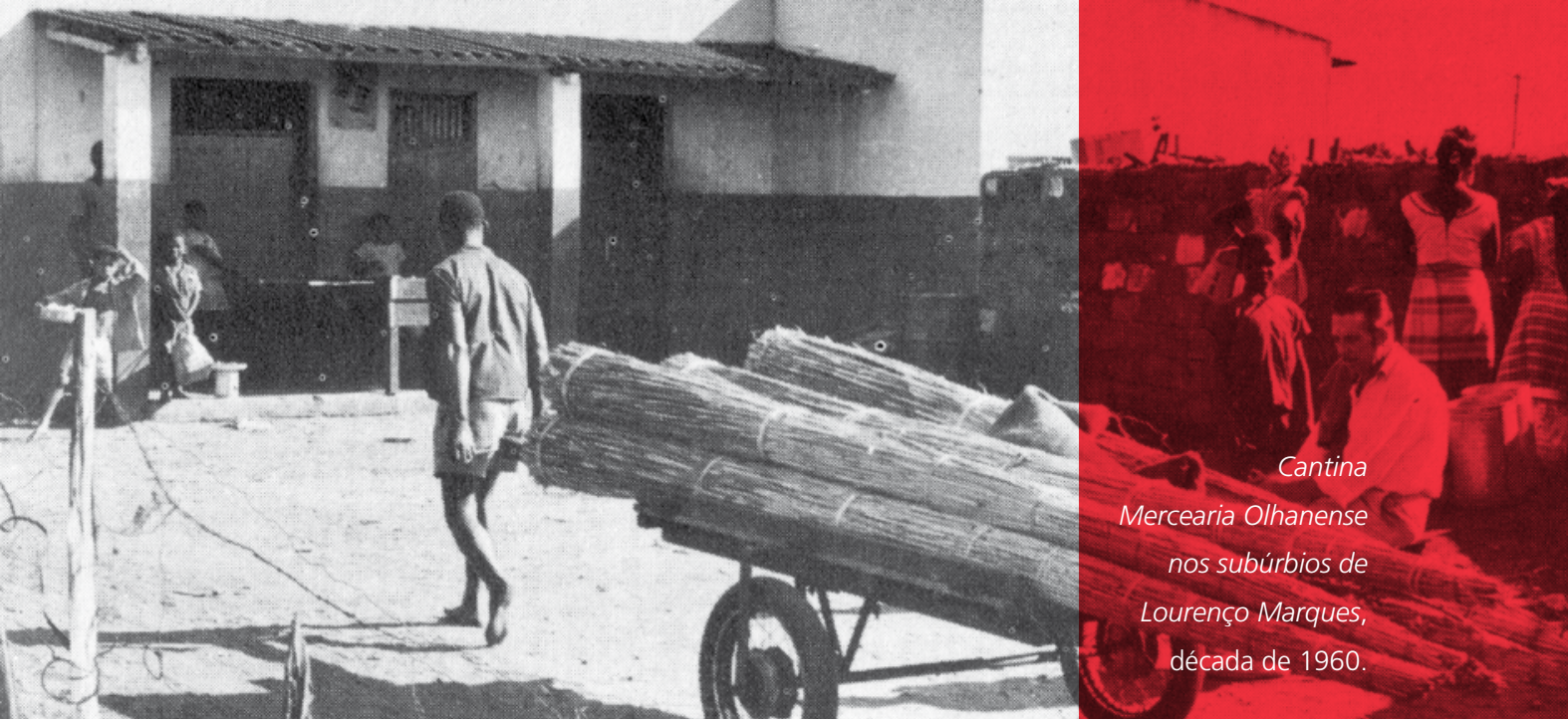

podíamos pagar, mas o cantineiro não se importava. Continuava a dar-nos crédito e passava o valor da dívida para o mês seguinte. À fome a gente não morria, como acontece hoje em dia. Se você não tem dinheiro você está mal. (Carlos Bruheim, 2013)

\section{Quanto às casas e aos habitantes diz-nos:}

Não se deixavam construir casas de alvenaria. As casas de duas águas eram de pessoas poderosas. O aluguer era 50 escudos por mês, nas casas de duas águas a renda era 250 a 300 escudos mensais, mas estas não tinham casa de banho interior. Usavam os baldes que eram recolhidos à noite pelos funcionários da salubridade do município.

Havia na Mafalala uma miscelânea de raças e etnias. Pois tínhamos chineses, indianos, na sua maioria comerciantes, macuas, gregos, estes na sua maioria padeiros. Era o caso das famílias Papucides, Eskiakis, Esculudes e Adrianopoulos. A convivência era sã e sem problemas de qualquer espécie. (Carlos Bruheim, 2013)

Mas um dos aspetos seguramente mais relevantes no seu testemunho são as recordações de infância e a carreira desportiva. Recorda:

Tive uma infância normal como qualquer criança dos subúrbios. Recordo-me das almoçaradas de caril de amendoim de carne em casa da minha avó, que acontecia de forma religiosa, todas as segundas-feiras. 
Éramos muitos irmãos e primos. Comíamos pela mesma travessa disputando as carnes. Era divertido. Lembro-me também dos bolinhos de coco com arroz, feitos pela Dona Manesha - senhora negra, da llha de Moçambique - mulher do chefe da esquadra, que estava situada ali no Mukumula, aonde hoje é a Unidade 23. Estes bolinhos, Mukhatsi, custavam $1 \$ 50$ escudos e gostávamos de tomá-los bem quentinhos com chá ao meio da tarde. Uma coisa interessante em relação ao chefe da esquadra é que vivia no mesmo recinto com a família e os presos ficavam na parte de trás da casa. Isso para mim era estranho porque havia aquela ideia dominante de que os presos tinham que estar fechados, mas ali a gente via-os livres, a varrer o pátio e a conversar. A minha infância foi permeada por muita atividade física, quer dizer éramos muito ativos. Pratiquei atletismo, mas por pouco tempo. Pois acabei por jogar futebol. Mas antes de falar da minha carreira gostaria de contar um episódio interessante. O meu pai e os meus tios também jogaram futebol. Jogaram pelo Munhuanense Azar como avançados e, pelo facto a linha avançada deste clube ficou conhecida como a dos Catembes. Pois o meu pai Francisco Bruheim era o extremodireito, Ernesto Bruheim - pai da Flora Bruheim e sogro do Eusébio - avançado centro e Carlos Bruheim, extremo-esquerdo. Eram naturais da Catembe, portanto eram os Catembe.

Em relação à minha carreira desportiva, como estava a dizer, saí do atletismo pela mão de um senhor que achou que eu tinha maiores possibilidades de brilhar no futebol, apesar de ter sido campeão de salto à vara, aos 15 anos de idade pelo Ferroviário de Lourenço Marques. Assim, entrei para a equipa de futebol do Ferroviário, aonde fiz toda a minha carreira desportiva, até 1974. Não joguei em Portugal devido aos empresários e dirigentes desportivos que queriam lucrar com a minha saída. Pois, em 1969, em Coimbra, fui disputar a taça de Portugal pelo Ferroviário e tive vários convites. Do Benfica, Penafiel e Académica, mas estas propostas todas foram por água abaixo devido aos motivos já mencionados. Destaquei-me como guarda-redes, apesar do meu 1,69m, era considerado o homem elástico. Mesmo não tendo atingido uma carreira internacional de relevo, fui uma presença regular nas seleções nacionais de Moçambique. Cheguei a jogar com Eusébio como adversário, nos Juniores e Seniores. (Carlos Bruheim, 2013) 
Yussuf Aboobakar, natural da Mafalala, procura a origem do bairro. Nas suas palavras:

Era chamada Mafalala a zona que se estendia da Marien N'Gouabi (ex-Caldas Xavier) até à mesquita Cadria (Mussiquitsi) dos Macuas e Mat/hohlomana"27. A partir destes locais até ao atual bairro Magude aonde era a antiga lixeira e sucata Ramos chamávamos munhuana e dizíamos que íamos às lagoas. Surge o nome de bairro Magude neste local porque, durante a guerra entre a Frelimo e a Renamo, grande parte da população proveniente desta região acabou por se instalar neste local. E, assim, a população da Mafalala, com o humor e sentido de oportunidade característico, passou a chamar àquele local bairro Magude. (Yussuf Aboobakar, 2012)

E a partir de um grupo específico - os comoreanos - recorda a vida cultural noturna das várias comunidades do bairro:

Na Associação Beneficente Comoreana havia bailes todas as 4. ${ }^{\text {as }}$ feiras, sábados e domingos, isto por volta dos anos 40 e tal. E já nessa altura havia meninas livres. Os comoreanos não dançavam porque era proibido para um muçulmano pegar a mulher de outro homem e por isso dançar para eles é haramo (proibido). Eles alugavam as suas instalações a terceiros e, neste caso, o Atlético Mahometano é que estava ali e organizava bailes. O Daíco tocava ali. Ele era um bom guitarrista. Para além dele tocava o Chico Albasini, o Mudapana e Manuel Levi, que mais tarde converteu-se ao islamismo. Este local era tão famoso que até vinham indivíduos brancos. Vinham marinheiros de várias nacionalidades à procura de diversão e mulheres negras. (Yussuf Aboobakar, 2012)

Estes contactos e vivências culturais foram fundamentais para a formação da sua consciência política no quadro do regime colonial. Como lutador pela libertação relembra a sua ação política e a importância do bairro nesta luta:

Fiquei preso na Machava como preso político em 1961 por fazer parte do primeiro grupo de nacionalistas moçambicanos que começou a pensar na independência política de Moçambique. Fomos alvos do primeiro 

julgamento militar da história de Moçambique, realizado no Tribunal Militar de Lourenço Marques, em 1962, no atual Quartel-general, de que fazia parte o Nuno Caliano, eu, Abdul Carimo e Ibrahimo Manguço, Guerra Manuel, Abissinia Aly, Abdul Carimo. Em nossa defesa veio um grupo de advogados portugueses que se consideravam da oposição portuguesa, nomeadamente Dr. Felipe Ferreira, Santa-Rita, Almeida Santos, Antero Sobral, Adrião Rodrigues, Raposo Pereira e Pereira Leite. Devido à ação destes advogados fomos absolvidos, porque estes provaram que não havia matéria para a nossa prisão. Este grupo, após o 25 de Abril, passou a chamar-se Democratas de Moçambique. (Yussuf Aboobakar, 2012)

\section{Nesta linha, um outro entrevistado, Guerra Manuel $^{28}$, revela em relação ao movimento político que começa a emergir em Moçambique na década de 60:}

A tomada de consciência política por parte dos moçambicanos ao longo da década de 60 foi um processo natural, pois esta década foi marcada pela independência de vários países africanos e parecendo que não isto acabou por nos influenciar. Acompanhávamos atentamente as notícias do mundo e de África em particular. A negritude, o pan-africanismo, a independência do Gana e Kwame Nkrumah, a Revolta dos Mau-Mau no Quénia e Patrice Lumumba exerceram uma grande influência sobre nós. Começámos a perceber que era possível tomarmos conta do nosso destino, estarmos livres e independentes. E assim entrou o bichinho da luta pela independência. Tínhamos encontros na casa do Caliano, do Nuno Caliano. À noite, em casa dele, discutíamos as noticias que nos chegavam sobre os movimentos independentistas em África. Os encontros eram na Mafalala ou Chamanculo em casa de um outro elemento que também fazia parte do grupo. Fomos ao julgamento, em 1962, o nosso foi o segundo depois do Virgílio de Lemos, poeta, que tinha chamado à bandeira portuguesa capulana e, por isso, foi levado a julgamento. Então o nosso foi logo a seguir a este, em 1962. Fomos os primeiros a ser julgados por um Tribunal Militar. Este realizou-se no Quartel-general, ali na Av. 24 de Julho. Fomos todos absolvidos, mas também tivemos uma equipa de defesa de luxo. Eu, Abissínia Aly, Hachimo Mussagy fomos defendidos pelo Pereira Leite. Éramos acusados de conspirar contra o regime colonial português. Mas fomos absolvidos por falta de provas. (Guerra Manuel, 2013) 


\section{Também este entrevistado sublinha a importância do desporto:}

Vivi na Mafalala, como disse, e joguei a nível do bairro. Nunca me federei, mas tive oportunidade de ver Eusébio jogar. O Magagaga, como era carinhosamente chamado pelos amigos do bairro, já aqui na Mafalala viase que era um craque, equipa em que ele estivesse a vitória era garantida. Eusébio passava o dia a jogar futebol, podia realizar dois a três jogos por dia sem problema nenhum, é por isso que ele revelou aquele poder atlético e felinidade que lhe valeu o título de pantera negra. Eu fazia parte da CUF da Mafalala, equipa por nós criada, no bairro que punha como condição para jogar o pagamento regular de quotas, e Eusébio, como não o fazia, não jogava. E isso custou-nos caro, porque ele chateado com a nossa atitude oferecia-se para jogar a todas as equipas que jogassem contra nós. Ainda sobre Eusébio, lembro-me de ter ouvido alguém aqui no bairro a compará-lo ao Seminário - jogador de origem peruana e famoso do Sporting - nestes termos: que o Seminário era um Eusébio melhor treinado. Surpreendentemente, alguns anos mais tarde, Eusébio tornar-se-ia num dos melhores jogadores do mundo. (Guerra Manuel, 2013)

\section{Um outro elemento abordado da vida do bairro e das suas discriminações é a prostituição:}

A prostituição era praticada no bairro, no mathlohlomana, e nas lagoas em frente ao Mica. Para ali, iam pessoas de diversas raças, e as mulheres que ali se prostituíam não eram naturais de Maputo. Eram de outras províncias, nomeadamente Gaza e Inhambane, mas a maior parte era de Gaza. A razão provável para este êxodo por parte delas pode estar relacionada com a violência doméstica e pelo facto de se ter pago o lobolo. Estas preferiam emigrar para não desonrarem a família, visto que esta já não podia devolver o valor pago. E assim a emigração para Maputo era a melhor saída e uma vez chegadas aqui, não tendo escolarização e nenhum tipo de formação, a solução era a prostituição para garantirem o seu sustento. Só podiam ser pessoas de fora de Maputo a dedicarem-se a esta atividade, porque as naturais de forma nenhuma se atreviam a tal. Os mecanismos de controlo social existentes não permitiam que estas o fizessem. Uma atitude do género era a desonra para a família. (Guerra Manuel, 2013) 
A situação da prostituição era tão grave que, logo após a independência, o presidente Samora Machel, também ele um habitante do bairro da Mafalala, a certa altura da sua vida, decide, numa das primeiras medidas tomadas, fechar o bar Vasco da Gama, localizado na Avenida de Angola, transformando-o na sede do partido Frelimo, da cidade de Maputo. O Vasco da Gama tinha sido um dos principais centros de prostituição na zona suburbana. O projeto revolucionário de criação do homem novo colidia com estas práticas, vistas como fruto de uma sociedade burguesa decadente.

Um elemento muito importante na urbanização do bairro era o tipo de construção que se fazia, normalmente ligada a artistas habitantes e aos materiais utilizados no sul do país que divergiam dos do norte. Abissinia Aly, nascido na Mafalala, em 1937, testemunha essas adaptações. Afirma que seu pai veio deportado de Mossuril por não aceitar pagar o imposto.

Os macuas eram na sua maioria tripulantes que chegavam a Lourenço Marques e acabavam por aqui se estabelecer, pois constituíam família e acabavam por ficar. Para além de tripulantes, muitos tornavam-se carpinteiros e grande parte das casas de madeira e zinco da Mafalala foram por eles construídas. Havendo até carpinteiros que eram bastante solicitados pela qualidade do seu trabalho. É o caso dos carpinteiros: Nhassope, Ngadide Nhabibo e Abdala Janeiro. Estes senhores construíram grande parte das casas de madeira e zinco da Mafalala. Quanto às casas de alvenaria estas começaram a ser construídas nos anos 40. (Abissinia Aly, 2014)

A propósito da introdução das casas de madeira e zinco em Lourenço Marques, Laranjeira (2012: 7) afirma que o zinco terá sido introduzido em finais do século XIX, resultado do Tratado de 1853, que abriu os portos de Moçambique ao comércio mundial. Segundo o autor, o zinco seria de origem alemã e inglesa e a madeira do báltico. As casas começaram por ser habitações simples um pouco elevadas do solo, com uma sala e dois quartos e uma sala de jantar e, num bloco separado, a cozinha, a dispensa e a retrete. Outro fator que poderá ter contribuído para a expansão deste material foi a proibição do uso de capim nos telhados a partir de 1876, após o incêndio que atingiu a povoação (Laranjeira, 2012: 7). 
Finalmente, também muito importante no bairro eram as autoridades gentílicas. Como nos diz o nosso entrevistado:

As pessoas dizem que o Sumalgy é régulo da Mafalala, mas na verdade ele é um simples induna. Alguém de confiança que passa a responder por esta área devido à sua idoneidade. O régulo, se é que podemos chamá-lo assim, estava localizado na munhuana. Era o régulo Luís, este não descendia da autoridade tradicional que controlava esta região. Os chefes tradicionais desta região são os Mpfumos. Pois estes controlavam a região que compreende a Maxaquene, Malhangalene, Munhuana e Mafalala. O régulo Luís, assim como o Sumalgy, foi uma criação do estado colonial. O régulo Luís, em termos hereditários, devia ter herdado o regulado dos Zuculas que controlavam o Xipamanine e Chamanculo. Como pode ter reparado, o Sumalgy nem era natural de Maputo, mas sim macua de Nampula. Mas devido à sua conduta acabou por ser aceite por todos. Isso contribuiu para reforçar a imagem de que a Mafalala era terra dos macuas. (Abissinia Aly, 2014)

Para terminar este rápido registo de vozes da Mafalala, os depoimentos sobre o 7 de Setembro confirmam o bairro como um dos locais onde a consciência política dos seus moradores era forte.

Quando aquele grupo de colonos portugueses inconformados com a irreversibilidade da independência dos moçambicanos tomou o Rádio Clube, aqui na Mafalala, a casa dos Calianos tornou-se o centro da estratégia para desalojá-los da rádio. E assim reuniu-se um grupo de pessoas vindas do Chamanculo, da Mafalala e tropas portuguesas, que se dirigiram para a rádio e desalojaram os colonos. Foi interessante ver o movimento de solidariedade que se estabeleceu entre a população e este grupo. As pessoas davam aquilo que tinham aos que se encontravam reunidos nos Calianos. Era um termo com chá, biscoitos ou pastéis, iam lá deixar, portanto, houve um movimento de solidariedade espontâneo. Não se obedeceu à ordem de alguém. (Sebastião Madeira, 2014) 



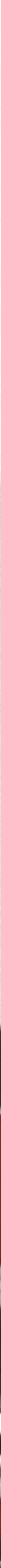


Teresa Caliano ${ }^{29}$ - mãe coragem - por seu turno diz-nos o seguinte:

A minha casa tornou-se o centro do movimento de defesa do bairro da Mafalala e daqui partiu o grupo que foi libertar a Rádio Clube das mãos dos colonos portugueses que a tinham ocupado. Estes não aceitavam o facto de a independência dos moçambicanos estar próxima. Devido à ação que o nosso grupo teve, a minha casa ficou conhecida como a base Galo e eu como mãe coragem. Foram dias inesquecíveis. Foram quatro dias de intensa atividade, que felizmente terminaram bem, a nosso favor. Quem comandou o assalto à radio foi o Aurélio Le Bon, que tinha sido comando e por isso a pessoa indicada para levar a cabo esta missão. E combinámos que quando ele tivesse a situação sob controle a senha seria, "Galo, Galo, amanheceu", assim ficámos a saber que a missão tinha sido bem sucedida. Foi devido ao nosso trabalho aqui na base Galo que a Mafalala não sofreu os atos de vandalismo que houve nos outros bairros. Dois factos interessantes a relatar é o facto de um dos jovens, o Isaías Tembe, que foi integrado na vigilância e proteção do bairro, ter sido capturado pelos portugueses do FICO e dos Dragões da Morte. Uma vez capturado foi levado à rádio, mas os nossos miúdos tinham sido instruídos para dizer que faziam parte da 25. ${ }^{\text {a }}$ quinta brigada da FRELIMO e que esta cercava a cidade e esperava ordens superiores para proceder ao ataque final. Dito e feito, o Isaías assim procedeu e quando disse isso aos seus captores estes trataram de devolvê-lo à Mafalala e pediram-lhe para informar aos seus superiores que não havia necessidade de se fazer o ataque. Outro facto interessante que ilustra a seriedade com que a vigilância do bairro era feita naqueles dias foi retenção dos generais Chipande e Gruveta, que tinham vindo ao bairro para visitar o irmão do falecido presidente Samora, o Josefate Machel, também falecido. Eles foram travados nas barricadas porque não conheciam a senha. (Teresa Caliano, 2015)

Estas são as histórias da Mafalala através das vozes dos seus habitantes que nos recordam acontecimentos que, de forma intermitente, vão desde os anos 30 até à independência. São vozes que nos ajudam, de uma maneira única, a conhecer o bairro que este livro pretende apresentar. 


\section{Considerações finais}

Os testemunhos reunidos de alguns moradores da Mafalala no trabalho de investigação que realizámos, no âmbito do projeto de elaboração da história oral do bairro, contam-nos diferentes histórias e percursos. Fica claro que nem todos têm a mesma versão dos acontecimentos, mas experiências de vida diferentes. Os depoimentos são de vozes anónimas, o que constitui uma vantagem e uma novidade, pois esta é uma abordagem pouco habitual em relação à Mafalala, tão ligada e sempre associada a figuras famosas, que naturalmente se assumem como os dignos porta-vozes e representantes do bairro. Ao abordarmos a Mafalala a partir de vozes anónimas questionámos a leitura do bairro apenas através das suas figuras famosas. Fizemos esta história do bairro não tanto a partir das biografias dos poetas, intelectuais e políticos que aqui habitaram e que nos fazem, ainda hoje, ver o bairro como um dos berços da independência, mas analisando o significado cultural e político que a mistura social na Mafalala proporcionou através de outras vozes. Como vimos, as diferentes origens geográficas e étnicas dos habitantes do bairro e os trabalhos que estes desenvolveram na cidade - que ia das fábricas aos Caminhos de Ferro, passando por lojas e casas de colonos aos homens do porto e às prostitutas - levaram a que aqui se formassem progressivamente pequenos grupos culturais e desportivos, onde começaram a germinar reflexões sobre a situação política e, especificamente, sobre a situação de subalternidade dos habitantes da Mafalala em todo o processo colonial em que estavam envolvidos. 


\section{Notas}

1 Informação dada por Abssinia Aly, Humberto Benfica.

2 É o caso do velho Muravira que morreu com cerca de 90 anos. Chegou por acidente a Moçambique, após o naufrágio do barco em que viajava por volta dos anos 50 , tendo aportado na baía de Porto Amélia, hoje Pemba. As autoridades portuguesas transferiram-no para Maputo para tratar das diligências diplomáticas. Voltou ao seu país de origem e regressou pouco depois para trabalhar e viver, segundo informação do próprio.

3 Issulay Bino Hagy, descendente de comoreano.

4 Marrabenta é um dos principais ritmos urbanos moçambicanos da região sul. Para mais informação ver Laranjeira (2014).

5 Ver Arquivo Histórico de Moçambique, Fundo da Administração Civil, Agremiações Recreativas e Culturais, caixa n. ${ }^{\circ} 12$.

6 Marongas é a designação usada para os naturais da Província de Maputo.

7 Machangana é a designação usada para os naturais da Província de Gaza.

8 Bitongas é a designação usada para os naturais da Província de Inhambane e falantes de guitonga.

9 O lobolo é o equivalente ao dote, em que o jovem nubente desembolsa o valor estipulado pela família da noiva para desposá-la. Esta prática verifica-se na região sul de Moçambique, região essencialmente patriarcal.

10 Informação dada por Abissínia Aly.

11 Unce, música urbana de origem árabe.

12 Mukumula, de acordo com alguns dos nossos entrevistados, era a zona onde vivia um senhor proprietário de terrenos que, devido à sua dureza na cobrança aos inquilinos, ficou assim conhecido por exigir que estes desfizessem a casa, caso não reunissem a quantia necessária para pagar a mensalidade.

Mufundisse, na língua ronga significa professor.

14 De acordo com um dos netos, Samora Correia terá obtido os terrenos na Mafalala como oferta de um general português de quem terá sido ajudante de campo durante o processo de ocupação efetiva, em 1895.

"Desfaz a tua casa; retira a tua casa daqui e desaparece".

16 Grupo étnico proveniente da região centro de Moçambique.

17 Segundo Sebastião Madeira Mandlakazi é uma palavra de origem Zulu que significa mãos de mulher.

18 Líder espiritual muçulmano que orienta as orações na mesquita.

19 Minkadjuíne é um bairro suburbano, vizinho da Mafalala, situado ao longo da Avenida de Angola. Na língua ronga a população passou a chamar Minkadjuíne ao bairro, que quer dizer zona de cajueiros. 
Assim chamado por ter nascido no ano em que a Coca-Cola foi introduzida em Moçambique, segundo Cássimo David.

21 Chamado Two batata porque, quando era jogador de futebol, por jogo não marcava menos do que dois golos.

22 Designação local para malfeitores.

23 Paulino Santos Gil detinha o monopólio da limpeza e salubridade na antiga Lourenço Marques. Chegou a Moçambique em 1903, vindo de Portugal. Foi um empresário colonial que se destacou na área do comércio, indústria, agricultura e transporte marítimo. Protagonizou grandes empreitadas públicas, como o paredão da Avenida Marginal de Maputo, o edifício do Conselho Municipal, o edifício onde se localiza o Café Continental e Estádio Paulino Santos Gil, hoje Desportivo do Maputo (Jornal Almourol, Jan/Fev, 1998). Gato Preto é o nome de uma das cantinas da Mafalala.

25 Moçambola é a principal prova futebolística moçambicana.

26 O magricelas na língua ronga.

27 Mathlolhomana é o nome atribuído ao antigo proprietário de um dos compounds situado na Mafalala onde se desenvolveu a prostituição. O proprietário era um indivíduo branco, antigo guarda-fiscal. O nome mat/hot/homana na língua ronga é atribuído à galinha que ataca para proteger as suas crias. A este ato chama-se ku-t/hot/homa; ao lugar onde ocorrem ataques do género chama-se ka-mat/hot/homana.

Guerra Manuel foi jornalista do Diário de Lourenço Marques, O Brado Africano, A Tribuna durante a década de 60 e, após a independência, colaborou no Jornal Notícias, Domingo e Savana.

29 Esposa do falecido Nuno Caliano, nacionalista de primeira hora. A sua casa, neste caso, a base Galo, foi base do movimento, que procedeu à proteção do bairro. 


\section{Bibliografia}

Cabaço, José Luís (2009), Moçambique: identidades, colonialismo e libertação. São Paulo: Editora UNESP.

Centro de Estudos de Desenvolvimento do Habitat da Universidade Eduardo Mondlane (CEDH-UEM) (2006), Moçambique: Melhoramento dos Assentamentos Informais (vol.1); Análise da Situação e Proposta de Estratégias de Intervenção (vol.2). Maputo: Direcção Nacional de Planificação e de Ordenamento Territorial.

Craveirinha, José (1969), "O Folclore Moçambicano e as suas tendências", O Cooperador de Moçambique IV (7).

Domingos, Nuno (2009), "As Políticas Desportivas do Estado Colonial em Moçambique", Lusotopie XVI (2): 83-104.

Freitas, Romeu Ivens Ferraz de (1965), Conquista da Adesão das Populações. Lourenço Marques: Serviços de Centralização e Coordenação de Informações.

Laranjeira, Rui Augusto (2014), A Marrabenta: Sua Evolução e Estilização, 1950-2002. Maputo: Minerva Central.

Laranjeira, Rui Augusto (2012), "Mafalala: quem te conhece não te esquece jamais", Caniço, n. ${ }^{\circ}$.

Lemos, Manuel Jorge Correia de (1987), "Maputo, deste lado da baía: considerações sobre a toponímia da cidade", Boletim do Arquivo Histórico de Moçambique, n. ${ }^{2}$ (especial): 5-18.

Lemos, Manuel Jorge Correia de (1988), "Reviver a Ilha, na Mafalala", Boletim do Arquivo Histórico de Moçambique, n. ${ }^{4}$ (especial): 49-58.

Liesegang, Gerhard (1987), "Lourenço Marques Antes de 1895", Boletim do Arquivo Histórico de Moçambique, n. 2 (especial): 19-75.

Lima, Alfredo Pereira de (1966), Edifícios históricos de Lourenço Marques. Lourenço Marques: Livraria Académica.

Lima, Alfredo Pereira de (1971), História dos caminhos de ferro de Moçambique. Lourenço Marques: Administração dos Portos, Caminhos de Ferro e Transportes.

Mendes, Maria Clara Teles (1985), Maputo antes da independência: geografia de uma cidade colonial. Lisboa: Instituto de Investigação Cientifica Tropical.

Moreira, José (1997), Os assimilados, João Albasini e as Eleições, 1900-1922. Maputo: Arquivo Histórico de Moçambique. 
Pereira, J.G.T. (1972), Relatório da inspecção ordinária ao 2. Bairro do Conselho de Lourenço Marques. Lourenço Marques.

Rocha, Aurélio A. N. (2006), Associativismo e Nativismo em Moçambique: Contribuição para o Estudo das Origens do Nacionalismo Moçambicano (1900-1940). Maputo: Promédia.

Silva, Cristiane Nascimento da (2009), "A Nação Portuguesa e os muçulmanos de Moçambique", XXV Simpósio Nacional de História da ANPUH (Fortaleza): 1-8.

Thomaz, Fernanda do Nascimento (2009), "Projetos em disputa num projeto de Estado: relações políticas no sul de Moçambique (19071922)", XXV Simpósio Nacional de História da ANPUH (Fortaleza): 1-12. Zamparoni, Valdemir Donizette (1998), Entre Narros \& Mulungos. Colonialismo e paisagem social em Lourenço Marques c. 1890- c.1940 (Dissertação de Doutoramento). São Paulo: Universidade de São Paulo.

\section{Entrevistas}

Abissinia Aly, 11 de junho de 2014

Carlos Bruheim, 15 de março de 2013

Cássimo David, 10 de junho de 2014

Guerra Manuel, 20 de setembro de 2013

Issufo Aly, 10 de julho de 2014

Issulay Bino Hagy, 09 de julho de 2014

Mussa Daúde Ibrahimo, 20 de junho de 2013

Roberto Machava, 10 de junho de 2014

Sebastião Madeira, 12 de dezembro de 2014

Teresa Caliano, 25 de setembro de 2015

Yussuf Bin Aboobakar, 15 de julho de 2012 



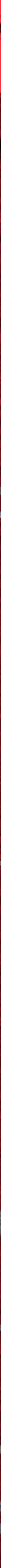

